\title{
Etnograficzne mapy bliskich terytoriów. Przestrzen wsi oczami społeczności lokalnej
}

\author{
Ethnographic maps of nearby territories. \\ The space of a village as seen by the local community
}

Mapa opowiada nie tylko o świecie, który przedstawia, ale także o perspektywie osób ją tworzących. Etnograficzne mapy niedużych miejscowości, powstające z udziałem mieszkańców, pozwalają pokazać je na większej skali i dzięki temu uwzględnić miejsca i przestrzenie znane z codziennych doświadczeń, na różne sposoby bliskie mieszkankom i mieszkańcom. Taki charakter mają mapy, które prezentujemy w tym artykule. Zostały stworzone w ramach dwóch różnych projektów, proces tworzenia każdej z nich wyglądał inaczej, ukazują trzy bardzo różne wsie, mające odmienne losy historyczne. Łączy je fakt, że powstały dzięki współpracy etnografek z mieszkańcami miejscowości, a przedstawione na nich treści wyłoniły się dzięki wspólnemu przyglądaniu się lokalnemu dziedzictwu. 
Na potrzeby naszych projektów nie przyjmujemy jednej definicji dziedzictwa ani tradycji, czerpiemy jednak z antropologicznej refleksji na temat tych pojęć. Podobnie jak Maria Małanicz-Przybylska (2016) zwracamy uwagę na semantyczne zbliżenie obu terminów. Chcemy je rozumieć możliwie szeroko, jako proces, w ramach którego poprzez odwoływanie się do przeszłości wytwarzane są nowe treści, mające znaczenie dla współczesności (Kirshenblatt-Gimblett 2011). W takim ujęciu dziedzictwo i tradycja mają charakter dynamiczny i kontekstualny (Shils 1984), odnoszą się do sposobów życia i działania konkretnych ludzi w konkretnych miejscach i czasach (Małanicz-Przybylska 2016). Są stale poddawane twórczym modyfikacjom po to, aby w danym momencie mogły być użyteczne dla osób, które się do nich odwołują (Ingold, Kurtilla 2000).

Mapy stworzone przez nas w ramach projektów nazywamy etnograficznymi z kilku względów - przede wszystkim powstały w wyniku badań etnograficznych i prezentują wiedzę lokalnych społeczności na temat otaczającej je przestrzeni. Etnolodzy w swoich badaniach często posługiwali się mapami, jako zarówno narzędziami badawczymi, jak i sposobem prezentacji wyników badań. W tym pierwszym znaczeniu używano zazwyczaj map wyobrażeniowych, aby nie narzucać uczestnikom badań perspektywy badaczki lub badacza, ale by poznać ich własną. Tak zwane mapy wyobrażeniowe, mentalne, pamięciowe czy poznawcze są przedmiotem zainteresowania wielu nauk społecznych. Klasyczne ujęcie tego tematu stanowi esej teoretyka urbanistyki Kevina Lyncha (Lynch 1960). Współcześnie badania map wyobrażeniowych można spotkać m.in. w etnologii czy geografii (np. Wojtaszczyk, Solarz 2016; Epsztein, Górna, Górny 2016). Mapy stały się też podstawą teorii etnologicznych w metodzie etnogeograficznej (Kłodnicki, Pieńkos, Koźmińska 2017), ale ze względu na inne założenia leżące u podstaw naszych badań i działań, nie używaliśmy tej metody. Wreszcie, mapy dla odwiedzających daną miejscowość i dla lokalnych mieszkańców stają się źródłem wiedzy i niejednokrotnie „odzyskiwania pamięci” (Bloch 2016), a dla nas są również sposobem na promowanie etnografii.

W projektach Stowarzyszenia „Pracownia Etnograficzna” mapy pełniły różne funkcje. Zaczynaliśmy od wykorzystania map najbliższej okolicy jako narzędzia edukacyjnego w ramach warsztatów etnograficznych. Pozwalały one uwspólnić wiedzę uczestników na temat ich miejscowości lub dzielnicy, ale też pokazać więzi, które łączą ich z otaczającą przestrzenią. Przykłady takiego wykorzystania map można znaleźć w naszych publikacjach: Nasze miejsce. Inspirator do pracy z lokalnościa (2016) oraz Nasze miejsce. Projekt edukacji etnograficznej dla dzieci i młodzieży (2020). W Etno-projekcie wKruszynianach, o którym opowiadamy w tym tekście, mapa z jednej strony posłużyła jako forma prezentacji wyników badań, z drugiej zaś stała się narzędziem integracji podzielonej wewnętrznie społeczności. Drugi z prezentowanych projektów - Etnograficzna mapa gminy Sępólno Krajeńskie - od początku zakładał tworzenie map, prezentujących zebrane opowieści mieszkańców. Praca z mapą nie tylko była sposobem opowiedzenia o wynikach badań, ale także stała się częścią procesu badawczego. 
W artykule pokazujemy, jak przebiegał proces powstawania map etnograficznych w dwóch badanych miejscowościach, Kruszynianach i łowie (czerpiemy także z doświadczeń tworzenia mapy Lutowa). Celem artykułu jest refleksja nad mapami etnograficznymi jako narzędziem pracy ze społecznościami lokalnymi i sposobem na oddanie głosu mieszkankom i mieszkańcom. Zastanawiamy się, jakie zalety ma wykorzystanie tego narzędzia oraz z jakimi wiąże się wyzwaniami. Skłania nas to też do refleksji nad charakterem wiedzy zdobytej i przedstawionej w ten sposób, a także nad wpływem naszych działań na badane społeczności.

\section{Jest w tej wsi coś niezwykłego. Opowieści o Kruszynianach}

Kruszyniany to niewielka wieś położona na Podlasiu w przygranicznej gminie Krynki, 4 kilometry od granicy polsko-białoruskiej. Tereny te to obszar Natura 2000, ostatnie w Polsce siedliska cietrzewia, czysta rzeka Nietupa. Kruszyniany to wieś wielu wyznań, wielu kultur. Przez wieki była miejscem, gdzie obok siebie mieszkali Polacy, Białorusini i Żydzi, wyznawcy islamu, katolicyzmu, prawosławia, judaizmu. Do dziś przetrwała jako miejsce, w którym stykają się kultury, religie i zwyczaje różnych grup wyznaniowych. Nadal mieszkają w niej Tatarzy, osiedleni tu 340 lat temu, którzy są polskimi muzułmanami, a także prawosławni, z których część uważa się za Białorusinów. We wsi jest meczet i cerkiew. Dziś to w sumie niewielka miejscowość, kiedyś jednak była znacznie większa i stanowiła lokalne centrum dla okolicznych wsi. Obecnie zimą mieszka tam kilkadziesiąt osób, latem znacznie więcej. Kruszyniańscy Tatarzy sprawili, że starzejąca się senna miejscowość odżyła i przyciąga rzesze turystów z całej Polski, ale też ze świata. Rocznie Kruszyniany odwiedza ok. 30-40 tys. osób.

Gmina Krynki, w której leżą Kruszyniany, starzeje się w szybkim tempie, rocznie umiera tu cztery razy więcej osób niż się rodzi. W Krynkach nie ma przemysłu, rolnictwo nie jest rozwinięte m.in. z powodu niskiej jakości ziemi rolnej. Bezrobocie wynosi niemal 19\%. Turystyka mogłaby być dobrze rozwijającą się branżą - to również w gminie Krynki leży słynny Wierszalin, osada stworzona przez „samozwańczego proroka", Eliasza Klimowicza (por. Pawluczuk 1974) - jednak władze gminy nie postrzegają jej jako pożądanego kierunku rozwoju. Same Krynki to dawne miasteczko żydowskie, z nadal stojącymi dwiema synagogami i ruinami trzeciej, z dwoma kirkutami i miejscem po jesziwie.

W 2019 roku Stowarzyszenie „Pracownia Etnograficzna” realizowało Etno-projekt w Kruszynianach, który pierwotnie miał polegać głównie na wsparciu Tatarów w działaniach związanych z kultywowaniem i rozpowszechnianiem ich własnego, unikalnego materialnego i niematerialnego dziedzictwa kulturowego'. W czasie pracy zakładali-

1 Z propozycją przygotowania wystawy i publikacji, upamiętniających 340-lecie osiedlenia się Tatarów Kruszynianach, zwróciła się do nas Tatarka z Kruszynian, Dżenneta Bogdanowicz. 
śmy ścisłą współpracę między przedstawicielami różnych dyscyplin oraz społecznością lokalną. Główny trzon zespołu stanowiły cztery etnografki, które w Kruszynianach prowadziły badania etnograficzne.

Ostatecznie w czasie badań skupiałyśmy się głównie na poszukiwaniu wielokulturowości wsi w opowieściach jej mieszkańców i innych osób związanych z Kruszynianami. Chcieliśmy podkreślić złożoną historię okolicy, opowiedzieć o tym, jak ludzie z różnych grup tworzyli jej rzeczywistość. Zbieraliśmy stare zdjęcia, legendy, opowieści o wsi, wspomnienia. Rozmawialiśmy ze starszymi mieszkańcami wsi, którzy spędzili w niej całe życie, ale też z osobami, które sprowadziły się do niej niedawno, bo chciały zamieszkać właśnie tu, na Podlasiu, w wielowyznaniowych Kruszynianach. Po zebraniu opowieści i materiałów archiwalnych próbowaliśmy znaleźć kontekst, który pozwoli opowiedzieć o Kruszynianach.

W przeciwieństwie do innych miejscowości, w których mieliśmy okazję wcześniej prowadzić badania, w przypadku Kruszynian niełatwo było znaleźć czynnik łączący wszystkie lub większość opowieści naszych rozmówców w jedną opowieść o wsi. Ostatecznie zdecydowałyśmy, że najważniejsze będą dla nas trzy kwestie: przestrzeń wsi, legendy i opowieści z nią związane, a także fakt, że Kruszyniany, dziś będące
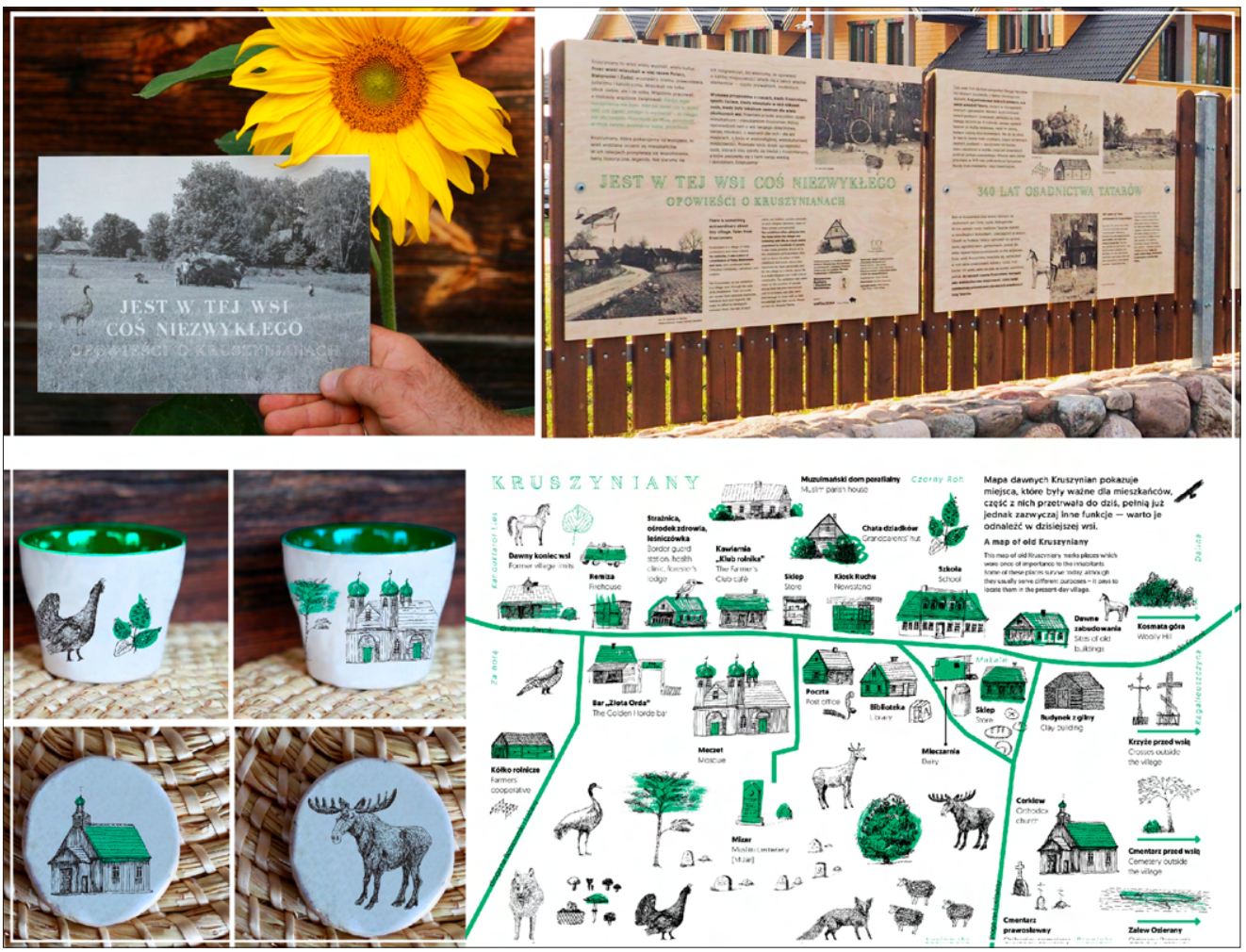

II. 1.

Materialne rezultaty projektu 
niewielką miejscowością, niemal całkowicie pozbawioną infrastruktury, dawniej stanowiły lokalne centrum. Wtedy właśnie okazało się, że najlepszym narzędziem, które pomoże nam przedstawić te trzy kwestie, będzie mapa wsi. Mapa stała się kluczem do zrozumienia dawnej roli miejscowości, pokazała, jak widzą ją jej mieszkańcy - ci, którzy mieszkają tu od pokoleń, ci, którzy się tu sprowadzili kilkadziesiąt lat temu, ale i ci, którzy zamieszkali tu, przyciągnięci niezwykłością wsi, jej historią, kulturą, otaczającą ją przyrodą. Na mapie zaznaczyłyśmy miejsca, które kiedyś były ważne dla mieszkańców. Część z nich do dziś istnieje, choć zazwyczaj pełnią inną niż kiedyś rolę. Mapa została narysowana ręcznie na podstawie archiwalnych zdjęć oraz współczesnego wyglądu budynków. Po zebraniu i opracowaniu opowieści przygotowałyśmy wystawę plenerową, która zawisła w Kruszynianach, a także publikację, opowiadającą o dawnej wsi. Stworzyłyśmy też projekt kruszyniańskich pamiątek z rysunkami z mapy, które można kupić w meczecie i które otrzymali też nasi rozmówcy. Wszystkie te materialne rezultaty projektu łączy spójna linia graficzna i kolorystyka. Opowieści, zamieszczone na mapie, poszczególne plansze wystawy i rozdziały książki pokazują wieś, jaka ukazała nam się we wspomnieniach mieszkańców - miejsce będące lokalnym centrum, w którym pracowano, modlono się, ale też bawiono.

Mapa Kruszynian znalazła się na wystawie poświęconej wsi, a także w publikacji, którą przygotowałyśmy w czasie projektu, funkcjonuje też jednak samodzielnie, uzupełniona opowieściami o zaznaczonych miejscach. Przeplatają się w nich wspomnienia, fakty historyczne, anegdoty i legendy. Nie staramy się ich rozgraniczyć, oceniać ich prawdziwości czy prawdopodobności, bo wierzymy, że opowieść o każdej miejscowości składa się z takich właśnie elementów - często prywatnych, osobistych. Wystawę i publikację zatytułowaliśmy: Jest w tej wsi coś niezwykłego. Opowieści o Kruszynianach².

Na mapie zaznaczałyśmy miejsca różnego typu - świątynie, cmentarze, budynki użyteczności publicznej, ale też miejsca związane z przyrodą, lokalnymi wierzeniami. Jednymi z ważniejszych były oczywiście te, które są związane z kruszyniańskimi Tatarami - w roku 2019, kiedy realizowałyśmy projekt, przypadała 340. rocznica osiedlenia Tatarów w Kruszynianach. W 1679 roku król Jan III Sobieski zamiast zapłacić Tatarom za ich służbę wojskową, nadał im ziemie, będące częścią dóbr królewskich. Pułkownikowi Samuelowi Murzie Krzeczowskiemu oraz jego towarzyszom przypadły Kruszyniany oraz tereny okolicznych wsi: Górki, Łużan, Białogorców. W tym samym czasie osadzono Tatarów również w nieodległych Bohonikach i otaczających je wsiach. Nie da się ukryć, że ziemie te były mało urodzajne, leżały na terenach zwanych „pustkami” - opuszczone lub słabo zaludnione w wyniku zniszczeń powstałych podczas potopu szwedzkiego. Osiadli na Podlasiu Tatarzy zajmowali się uprawą ziemi, ogrodnictwem, garbarstwem, jednak dla wielu najważniejsza pozostawała służba

2 Poniższa część tekstu powstała na podstawie publikacji Jest w tej wsi coś niezwykłego. Opowieści o Kruszynianach (Demski, Kojder, Kościańska, Płuciennik 2019). 
wojskowa. Przez wieki Kruszyniany zmieniały się, zamieszkali w nich także prawosławni, katolicy i Żydzi (Skorowidz miejscowości Rzeczypospolitej... 1924: 33). Wieś po raz pierwszy opustoszała w czasie bieżeństwa (por. Prymaka-Oniszk 2017), kiedy jej mieszkańcy musieli uchodzić w głąb Rosji. Po kilku latach część z nich wróciła, a Kruszyniany znów zaczęły tętnić życiem, wieś się zaludniła. W latach 60. i 70. XX wieku stanowiła lokalne centrum dla okolicznych miejscowości. W latach 80. zaczęła się ponownie wyludniać, ludzie wyjeżdżali do miasta i za granicę. Po 1989 roku Kruszyniany ponownie opustoszały. Sytuacja zmieniła się na początku XXI wieku - zaczęli tu powracać potomkowie pierwszych osiedlonych 340 lat wcześniej Tatarów, wrócili inni mieszkańcy, sprowadzili się także ludzie, których zauroczył ten „koniec świata”.

Jednym z ważniejszych punktów na mapie Kruszynian jest meczet, stojący w centrum wsi. Jest drewniany, powstał w XVIII wieku, choć nie wiadomo, kiedy dokładnie. Warto porównać jego wygląd z wyglądem dawnej kruszyniańskiej cerkwi - są do siebie zaskakująco podobne. Mieszkańcy Kruszynian opowiadają, że oba budynki budowali ci sami cieśle, być może Żydzi. Za meczetem znajduje się mizar, muzułmański cmentarz. Najstarszy nagrobek, na którym można odczytać datę, pochodzi z roku 1699. Wiele rodzin tatarskich z całej Polski chowa lub odwiedza tutaj swoich zmarłych, chowani są tu także muzułmanie niebędący Tatarami. Jeden z naszych rozmówców, starszy prawosławny mieszkaniec Kruszynian, wspominał sadogę, słodki poczęstunek, który Tatarzy rozdają podczas pogrzebów. Te bułeczki były jednymi z niewielu słodkich rzeczy, jakie w dzieciństwie jadł:

Jak ktoś umarł, to przywozili furą. I przywozili bułkę, sadoga zwana taka. O Jezu, a tych dzieci było dużo, i starsze byli. Ja chcę bułkę wziąć, a ten starszy mnie popchnie i sam zabierze. Ja w płacz. Ale ktoś tam zauważyłi przyniósł i mnie daje. (...) I to takie naprawdę smaczne bułeczki robili. A tu wie pani, kiedyś, kto bułeczkę tutaj widział! To biedota była!³.

Z mizarem także związane są różne opowieści. Jedna z nich mówi o gawronach, których wielkie stado zagnieździło się nad cmentarzem: „Aż czarno było. Każde drzewo było obwieszone tymi gawronami. I przyjechał imam, modlił się chyba cały dzień, chodził od jednego do drugiego kąta mizaru. Następny dzień, ani jednego gawrona nie było. I do tej pory nie ma!". W innej wersji tej opowieści występuje bardzo pobożna żona imama, której udało się wymodlić ucieczkę gawronów, a w jeszcze innej gawrony odleciały, kiedy wycinano na mizarze stare drzewa.

Kolejnym punktem, związanym z Tatarami, który zaznaczyliśmy na mapie, jest należący do Muzułmańskiej Gminy Wyznaniowej Dom Parafialny, wykorzystywany podczas świąt. Była tu też, jak wspomina jeden z rozmówców, „biblioteka tatarska

3 Wszystkie cytaty, niezakończone wskazaniem źródła, pochodzą z badań prowadzonych przez etnografki ze Stowarzyszenia „Pracownia Etnograficzna” w czasie opisywanych w tekście projektów. 


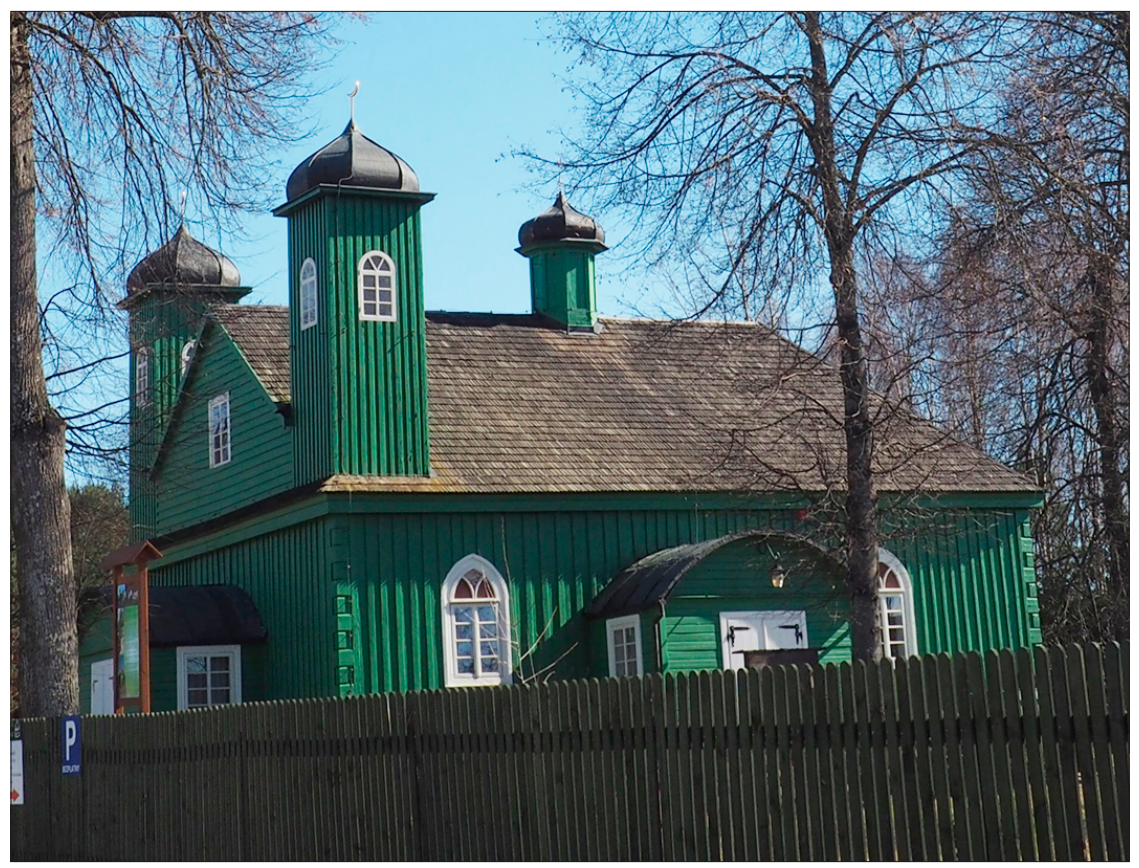

Fot. 1.

Meczet współcześnie; Kruszyniany, 2019 r.

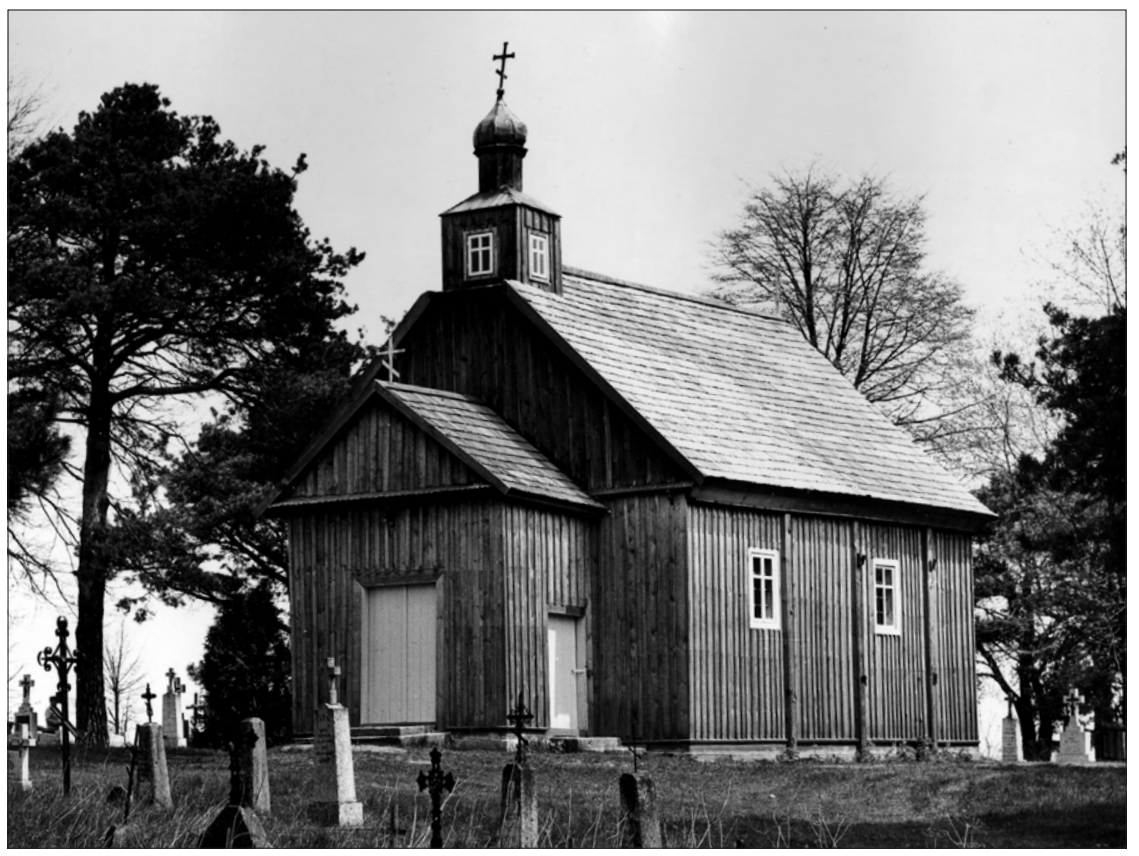

Fot. 2.

Dawna cerkiew; Kruszyniany 
i było Koło Młodzieży Tatarskiej. Po wojnie organizowano bale tatarskie, zjeżdżali z całej Polski Tatarzy, żeby się pobawić. To były bale w szczerym polu, ławki rozstawione, na świeżym powietrzu, duże, olbrzymie zabawy”. Obecnie w tym miejscu, w nowym budynku, znajduje się Centrum Edukacji i Kultury Muzułmańskiej Tatarów Polskich w Kruszynianach.

We wsi mieszkali także katolicy, prawosławni i - podobno - Żydzi. Pamięć o tych ostatnich niestety się nie zachowała, pojawiali się we wspomnieniach tylko jako możliwi budowniczowie cerkwi czy meczetu. Jak mówiła jedna z naszych rozmówczyń: „Ludzie tutaj, jakiej religii by nie byli, to zawsze są otwarci i nie powiedzą, że inny to jest gorszy, tylko jest inny." Prawosławny mieszkaniec Kruszynian wspominał za to: „Tu byli katolicy, prawosławni i Tatarzy. Matka mnie mówiła: słuchaj, różnicy nie rób. Jak matka mnie nauczyła!".

Wśród mieszkańców Kruszynian od dawna znaczną część stanowili prawosławni. Kruszyniańska drewniana cerkiew św. Anny, wybudowana w latach 20. XIX wieku, spłonęła w roku 1983. Na jej miejscu stanęła cerkiew murowana, o zaskakującej architekturze. Budynek świątyni jest otoczony cmentarzem, na którym najstarsze nagrobki pochodzą z XVIII wieku. Jego współczesne granice wyznacza kamienne ogrodzenie, jednak są też groby poza cmentarzem, ponieważ, jak mówił jeden z rozmówców, dawniej „cmentarz był większy, Przy drodze, po lewej stronie, jest taki dół i tam, pod ziemią, są stare groby". Wśród starych nagrobków zwraca uwagę jeden, przypominający nieco groby na mizarze: jest ustawiony w przeciwną stronę niż większość pozostałych, od strony nóg leży mniejszy kamień, od strony głowy większy, zwieńczony krzyżem prawosławnym. Przywołana przez jednego z rozmówców romantyczna legenda głosi, że jest to grób Tatara, który pokochał prawosławną kobietę tak bardzo, że aby się z nią ożenić, zmienił wiarę. Dziś w Kruszynianach także zdarzają się małżeństwa mieszane, międzywyznaniowe, w których każde z małżonków - a czasem i każde z dzieci - wyznaje inną religię. Jak mówiła jedna z rozmówczyń:

Dzieci korzystają podwójnie, bo mają i Mikołaja, i Bajramowe, bo na Bajram dostaje się kasę, więc i słodycze są, bo sadoga, więc no korzystają podwójnie. No i poznają dwie religie, uczą się tolerancji, tak, no że to się da, wszystko się da, tylko trzeba chcieć.

O dialogu międzyreligijnym świadczy też opowieść dotycząca postaci proroka Eliasza Klimowicza:

Jest taka historia, że Eliasz Klimowicz podobno przed tym, jak został czy jak już był prorokiem, to w Kruszynianach z imamem się spotkał, rozmawiali i imam potwierdził, że w nim jakaś jest charyzma, jakąś moc boską ma. Imam, duchowny twierdził, że jakąśs moc ma prorok prawosławny. Spotkał się imam z prorokiem i rozmawiali o panu Bogu, wierze w Boga i o posłannictwie. 
Na mapie zaznaczyłyśmy także nieco tajemnicze miejsce, położone 500 metrów przed wsią. Wśród traw leży tam kilkanaście głazów, od niedawna ogrodzonych niskim płotem, z ustawioną obok prostą kapliczką lampową. Mieszkańcy Kruszynian są zgodni, że jest to cmentarz. Nie wiadomo jednak, kto został na nim pochowany. Jedna z opowieści mówi, że był to pierwszy cmentarz tatarski, inna że chowano tutaj katolików zanim powstał cmentarz w Krynkach. Powiadano także, że mógł to być cmentarz morowy, na którym grzebano osoby zmarłe podczas epidemii - wszystkich, bez względu na wyznanie. Jeszcze inne historie mówią o tym, że to cmentarz żołnierzy Napoleona, wracających spod Moskwy. Najbarwniejsza z zanotowanych mówi jednak tak: „Dawno temu drogą naprzeciw siebie jechały dwa wesela. Żadne nie chciało drugiemu ustąpić, bo to przynosi pecha, i tak się tam ludzie pobili, że poumierali i po prostu gdzie zginęli, tam ich pochowano". Na niektórych kamieniach do dziś można znaleźć wyrytą datę.

Na mapie znalazły się także miejsca związane z rozrywką, zabawą, spędzaniem czasu wolnego. Jednym z nich była karczma Złota Orda. Sprzedawano tam piwo, kwas chlebowy w butelkach zamykanych korkiem, oranżadę, a także baranie szaszłyki: „Szaszłyki pamiętam. Może dlatego, że ich nigdzie indziej się nie jadło, a tu były, wiesz, na patyku, taki szaszłyk fajny". Sama karczma była za mała, by w niej zorganizować

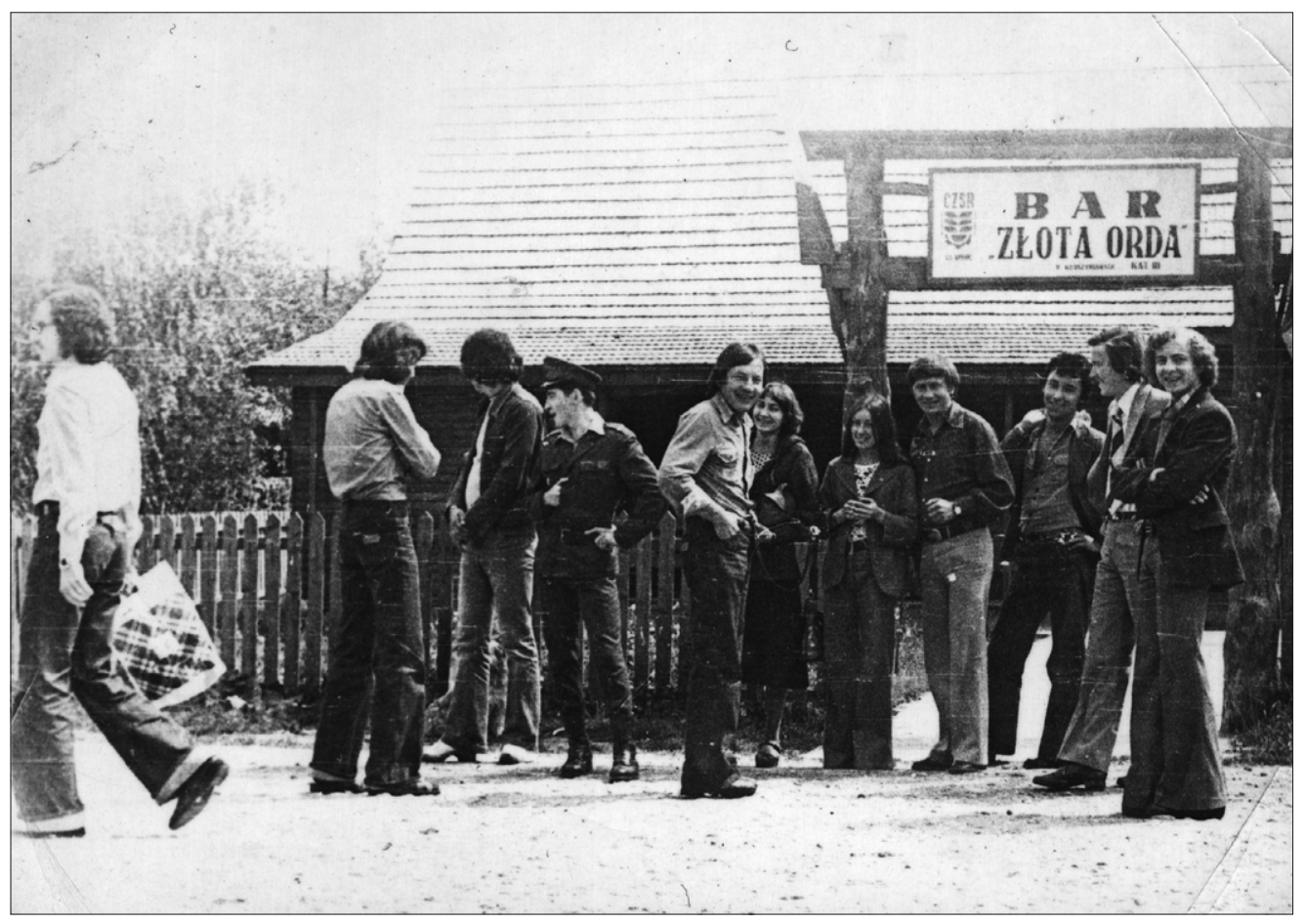

Fot. 3.

Młodzi ludzie przed barem Złota Orda; Kruszyniany 


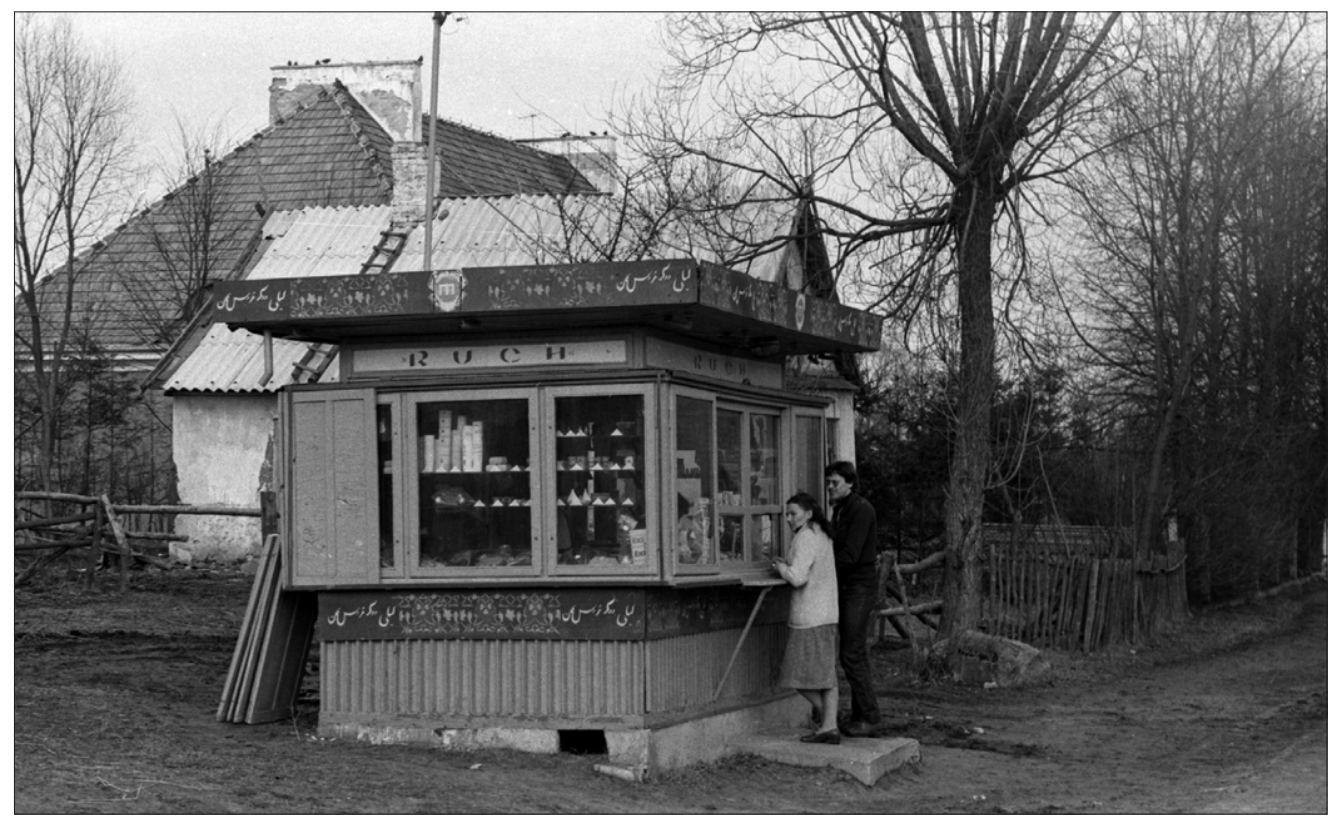

Fot. 4.

Kiosk Ruchu; Kruszyniany, 1979 r.

potańcówkę, więc co jakiś czas z desek się robiło tak zwaną płaszczadkę, czyli miejsce do tańczenia. „Z całej okolicy tu się przyjeżdżało, motorami, wueskami, kto co miał”. We wsi mieściło się także kółko rolnicze, gdzie można było wypożyczyć maszyny, a także kawiarnia Klub Rolnika, którą powołano w PRL-u w celu krzewienia kultury: „To właśnie miała być taka klubokawiarnia, dlatego że tam, nawet jeśli się piło alkohol, to kulturalnie, że były stoliki, były gazety, był telewizor. Czasem jedyny we wsi. I tak po prostu, wiesz, herbaty można się było napić". Budynki Złotej Ordy i Klubu Rolnika do dziś stoją w Kruszynianach, podobnie jest z remizą - dziś już nieczynną. Dawniej w tym niewielkim budynku na co dzień stał wóz strażacki z osprzętem, a od święta urządzano tu zabawy, potańcówki i wesela.

Dawniej w Kruszynianach można było zrobić zakupy, odwiedzić lekarza, wysłać list, podkuć konia, a także zdać mleko do mleczarni. Na mapie zaznaczyliśmy miejsca, związane z tymi aktywnościami. Jednym z ciekawszych punktów był kiosk Ruchu, znajdujący się w centrum wsi. Kształtem podobny do tysięcy innych kiosków w kraju, wyróżniał się jednak napisami w alfabecie arabskim, a raczej wzorem, przypominającym litery alfabetu ${ }^{4}$. W asortymencie miał prasę, kosmetyki i inne artykuły

4 Podczas badań kontaktowaliśmy się z wieloma osobami, próbując rozszyfrować napisy na kiosku, niestety to się jednak nie udało, stąd wniosek, że jest to raczej wzór, inspirowany arabskim liternictwem niż napis. W trakcie badań słyszeliśmy także, że kruszyniańscy Tatarzy, używający na co dzień podlaskiej gwary, zapisywali ją niekiedy właśnie alfabetem arabskim. 
przemysłowe, ale także pamiątki tatarskie. Jedna z dzisiejszych mieszkanek Kruszynian wspomina, że kiedy w latach 70. XX wieku po raz pierwszy w życiu przyjechała do wsi na groby swoich przodków, w tym kiosku właśnie kupiła ceramiczny meczet, szkliwiony na brązowo. Podczas badań udało nam się obejrzeć taki meczet na wystawie w Muzeum Historycznym w Białymstoku, a później także otrzymać taki od mieszkanki sąsiedniej gminy.

Na mapie zaznaczyliśmy także inne punkty, ważne dla niegdysiejszych Kruszynian. Obok kiosku Ruchu stała poczta z centralą telefoniczną, a później także budka telefoniczna, niedaleko była też biblioteka. Znajdowało się tu też kilka sklepów, z którymi wiąże się wiele wspomnień mieszkańców. Jeden sklep znajdował się na początku wsi: „rolnik, dowoził tu wszystkie towary konikiem”, sprzedawano w nim „wszystko. Marmoladę. Konserwy. Ocet. Mielonkę. Wodę Krynkę, oranżadę", sklep był też ważnym punktem wymiany informacji. Wspomnienia dotyczyły też smaków, zapachów:

Pieczywo z piekarni rozwozili traktorami, przyczepami, z drutu takie kosze były wielkie i w nich gorący chleb, taki jasny, jajowate bochenki. I stoisz w sklepie, czekasz na ten chleb, wiesz, kolejki, bo chleb przywożą, pachnie, gorący! I jak się wracało ze szkoły, trzeba było chleb kupić do domu. To się kupowało dwa, z czego do domu docierałjeden. Bo się zjadało po drodze, był tak pyszny.

Jeden z dawnych klientów opowiadał, że sklep bywał okradany:

przyjeżdżali ludzie nie wiadomo skąd, żukiem. Zaczepiali linę za kraty, wyrywali kraty. Wpadali do sklepu. Kradli całą wódkę. Papierosy. Trochę konserw. I sru, i nie ma! Były też takie wypadki, że ktoś się włamał i rano przychodzi sklepowa, tak jak na filmach się pokazuje, i leży dwóch kolesi, po prostu: co wypili, to wypili, coś tam zjedli. Reszta została.

Dawniej w wielu wsiach w okolicy Krynek istniały szkoły. Z biegiem lat likwidowano je, przenosząc dzieci do szkół zbiorczych. Jedną z takich placówek była szkoła w Kruszynianach, w której od lat 70. i 80. XX wieku chodziły dzieci z większości okolicznych wsi. Przywożono je, jak wspomina dawna nauczycielka, „samochodem dostawczym i dwiema przyczepami, krytymi, z okienkami, taką budą". Z czasem dzieci ubywało, na początku lat 90. szkołę więc zamknięto, a dzieci od tego momentu są dowożone do szkoły w Krynkach. Dziś mieści się tu pensjonat, ale budynek, zaznaczony oczywiście na mapie, bardzo się nie zmienił.

Kruszyniany leżą w otulinie Puszczy Knyszyńskiej, na mapie staraliśmy się więc uwzględnić także okoliczną przyrodę. Można na niej znaleźć lisa, łosia, cietrzewie czy żurawie, których klangor słychać od samego rana. Okoliczne lasy zaś to ulubione tereny wielu grzybiarzy. Jak mówi jedna z mieszkanek: „Sąsiadka nasza wychodzi i mówi: - Dzisiaj idę zbierać np. prawdziwki, innych nie zbieram. Jutro pójdę na inne 
grzyby. No i sobie idzie i wybiera". Na mapie zaznaczyliśmy też miejsca leżące wokół Kruszynian, z którymi wiążą się wspomnienia i historie zasłyszane w dzieciństwie. Jedna z nich dotyczy kurhanu - symetrycznego kopca o wysokości około 10 metrów. Mieszkaniec Kruszynian wspominał:

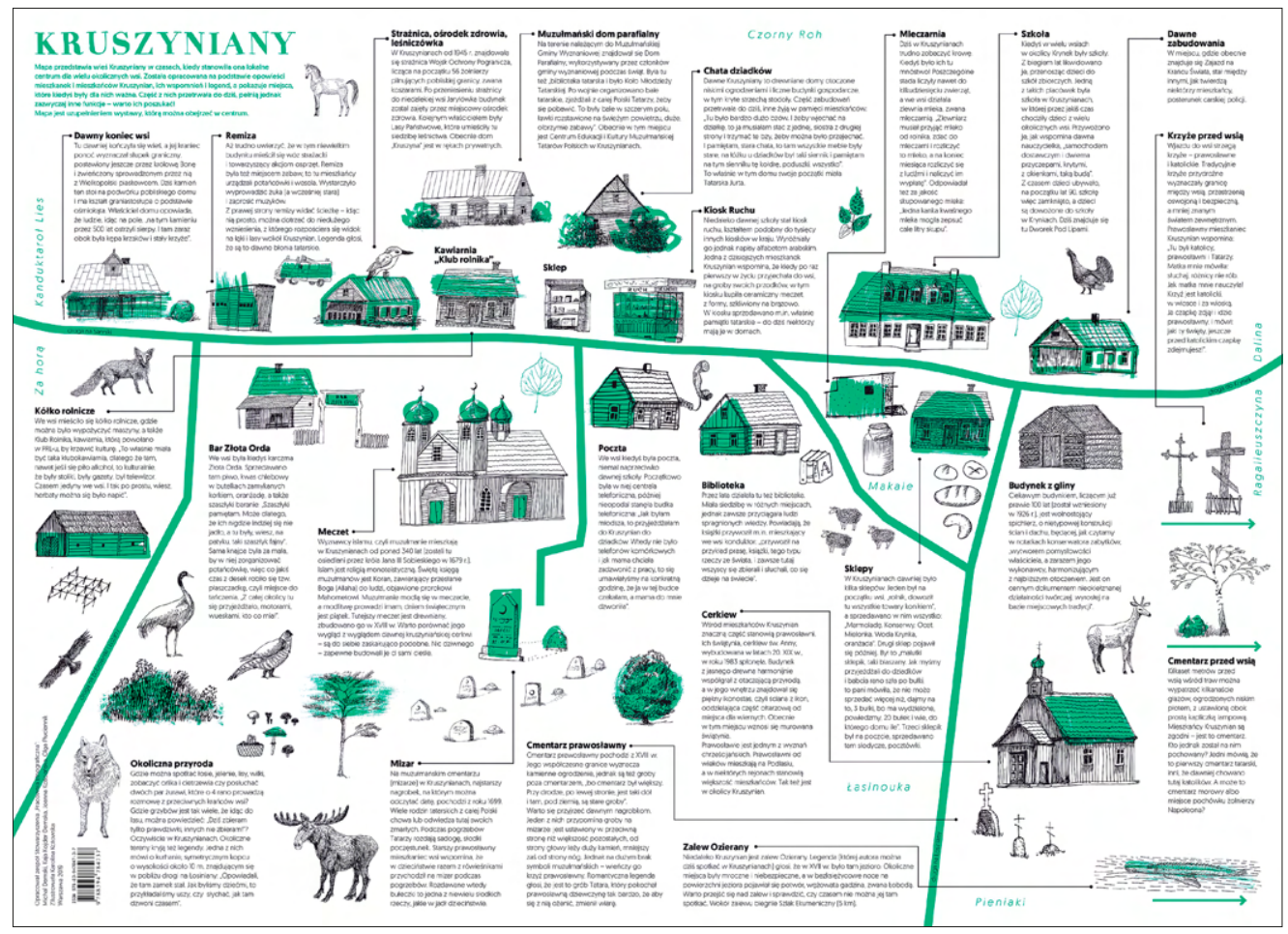

II. 2.

Mapa Kruszynian z opisami poszczególnych miejsc

Tata opowiadał mi o kurhanie. Teraz to wszystko zarosło i się wyrównało, ale tam był jakby taki kopiec usypany duży. Przy drodze na Łosiniany za skrętem na szlak ekumeniczny, a przed skrętem nad zalew, po prawej stronie około 100 metrów od drogi. Opowiadali, że tam zamek stał, jak byliśmy dziećmi to przykładaliśmy tam uszy, czy słychać, czy tam dzwoni.

W innej wersji opowieści jest to miejsce pochówku Samuela Murzy Krzeczowskiego. Niektóre legendy i opowieści powstały stosunkowo niedawno. Tak rzecz się ma z legendą o zalewie Ozierany, autorstwa jednego z mieszkańców Kruszynian, żyjąca jednak własnym życiem. Głosi ona, że w XVII wieku niedaleko Kruszynian było jezioro. Okoliczne miejsca były mroczne i niebezpieczne, a w bezksiężycowe noce na powierzchni jeziora pojawiał się potwór, wężowata gadzina, zwany Łobodą. Dziś 
w zalewie pływa potwór Łoboda, wyrzeźbiony z drewna. Inną legendę przytacza leśnik Adam Ciuńczyk:

Dawno temu najstarsze babcie w Kruszynianach opowiadały swoim wnukom - które dziś też są babciami i dziadkami - że kiedyś obok wsi płynęła rzeka. Nie była to duża rzeka, ot, rzeczka raczej, ale konie było gdzie napoić, mietusów i raków nałapać, a i wykąpać się było można. Miejscowe dzieciaki radochę miały co niemiara. Jednak taki dziki, przeważnie płytki, nieuregulowany ciek, miał to do siebie, że na zakrętach zdarzały się dość głębokie miejsca. Podczas kąpieli wpadła w taką "głęboczkę" pewna dziewczynka i utopiła się. Los chciał, że była to córka miejscowej czarownicy. Jak każda matka, nie potrafiła pogodzić się ze śmiercią dziecka. Z nienawiści w sercu do tej, która zabrała jej córkę, ścięła topielicy włosy i zatkała nimi źródło (Ciuńczyk 2013: 14).

Opowieści zebrane przez nas w Kruszynianach łączą się ze sobą, pokazując jak dawniej żyła wieś. Mapa stała się narzędziem umożliwiającym połączenie różnych narracji, opowiedzenie o rozmaitych częściach kruszyniańskiej społeczności. Dzisiejsze Kruszyniany nie są wsią pozbawioną konfliktów. Naszym celem było niepogłebianie ich, ale „oddanie" ludziom zebranych wspomnień w takiej formie, z którą łatwo im będzie się identyfikować. Przestrzeń i miejsca pokazane na mapie stały się elementami, które mogą spoić społeczność, niewykluczającymi nikogo, uwzględniającymi różne narracje i sposoby opowiadania o wsi. Mieszkańcy Kruszynian, oglądając gotowe mapy, szukali swoich domów, czytali opowieści o miejscach, niejednokrotnie reagując bardzo emocjonalnie, podając inne wersje zapisanych przez nas legend. Wydaje namsię, że opracowane przez nas materiały, w tym mapa, zostały dobrze przyjęte przez mieszkańców, mieszkańcy twierdzili, że grafika oddaje charakter zabudowań wsi.

\section{Etnograficzne mapy wsi lłowo i Lutowo w gminie Sępólno Krajeńskie}

Mapy Iłowa i Lutowa powstały w ramach projektu Etnograficzna mapa gminy Sępólno. Zgodnie z założeniami miał on na celu wzmacnianie tożsamości lokalnej przez wspólne odkrywanie i promocję miejscowego dziedzictwa kulturowego. We wniosku zakładałyśmy, że mieszkańcy gminy razem z etnografkami będą badać lokalne dziedzictwo i wspólnie z nimi przygotują mapę swojej miejscowości.

Koncepcja działania powstała na podstawie diagnozy lokalnego potencjału kulturotwórczego, przygotowanej przez Stowarzyszenie „Pracownia Etnograficzna” dla Centrum Kultury i Sztuki w Sępólnie Krajeńskim, które stało się partnerem projektu. Autorka diagnozy podkreśliła ciekawą spuściznę historyczną i dziedzictwo kulturowe gminy Sępólno Krajeńskie (m.in. zabytki poewangelickie, ale także charakterystyczną architekturę i tradycje krajeńskie). Zwróciła także uwagę, że do tej pory te zasoby w ograniczonym stopniu były wykorzystywane w działaniach animacyjno-kulturalnych, 
brakowało przedsięwzięć, pozwalających odkrywać lokalną przeszłość i dzielić się historiami swojej rodziny (por. Czyżewska 2019).

W projekcie zwracałyśmy szczególną uwagę na niematerialne aspekty lokalnego dziedzictwa, związane z pamięcią mieszkańców, przekazywanymi przez nich opowieściami i tradycjami. W ten sposób chciałyśmy wyjść poza najbardziej utarte sposoby opowiadania o lokalnym dziedzictwie, które skupiają się przede wszystkim na znanych zabytkach regionu. Bardziej niż historia zabytkowych obiektów interesowało nas to, jakie ludzie mają z nimi relacje.

Z diagnozy wynikało, że jednym z głównych wyzwań działalności kulturalnej był silny podział na miasto i wieś oraz niewielka znajomość okolicznych miejscowości wśród mieszkańców Sępólna Krajeńskiego. Autorka pokazała, że

Wieś jest także postrzegana jako mało atrakcyjna i interesująca. Szczególnie dobrze było to widać podczas warsztatów badawczych z nastolatkami (pochodzącymi zarówno z Sępólna, jak i ze wsi), gdy poproszone o wskazanie ciekawych miejsc w gminie, mówiły wyłącznie o miejscach z miasta (Czyżewska 2019: 35)

W rekomendacjach zaś znalazła się sugestia, aby proponować inicjatywy wychodzące poza stereotypowy wizerunek wsi, utożsamianej m.in. z folklorem i ludowością.

W projekcie planowałyśmy zwrócić uwagę na te dwa główne problemy: niedocenienie wiedzy mieszkańców i aspektów niematerialnych w projektach dotyczących lokalnego dziedzictwa oraz na podział na miasto i wieś, ze znacznie mniejszym naciskiem na działania kulturalne dotyczące wsi. Zakładałyśmy pracę z grupami mieszkańców dwóch wsi i stworzenie wraz z nimi mapy gminy, która uzupełniałaby te braki. Wspólnie z mieszkańcami i mieszkankami gminy chciałyśmy przyjrzeć się jej historii widzianej z perspektywy tych ludzi, którzy mieszkali tu kiedyś, tych, którzy mieszkają tu od dawna, a także i tych, którzy sprowadzili się w te okolice.

Te ogólne założenia przyszło nam wcielać w życie w niestabilnym czasie pandemii. Do ostatniej chwili nie miałyśmy pewności, w jakich miejscowościach i z jakimi grupami mieszkańców będziemy mogły pracować. Tak trafiłyśmy do łłowa i Lutowa - dwóch wsi położonych w stosunkowo niewielkiej odległości od siebie, w zachodniej części gminy Sępólno Krajeńskie. Ograniczyło to zasięg terytorialny planowanych map, skłoniło do pracy bardzo lokalnej, skupionej na pojedynczych wsiach. Metoda działania zakładała modyfikacje i dopasowanie się do lokalnych warunków, z czego wynikły różnice w realizacji procesu powstawania map w Iłowie i w Lutowie. Poniżej skupimy się na opisaniu prac w Iłowie, zaznaczając, że podobne działania toczyły się równolegle w Lutowie (Bińka, Orlikowska, Patzer, Płuciennik, Wojtaszczyk 2020a, 2020b).

Wsie, będące przedmiotem naszego zainteresowania, są położone na Krajnie, historycznym regionie rozciągającym się na pograniczu Wielkopolski i Pomorza, którego umowne granice wyznaczają rzeki: Kamionka z Debrzynką na północy, 
Noteć na południu i Gwda na zachodzie oraz rynna jezior byszewskich na wschodzie (Jakubowski 2018: 11). Geograficznie cały obszar Krajny tworzy Pojezierze Krajeńskie (Kondracki 2002: 79). Administracyjnie natomiast teren podzielony jest pomiędzy trzy województwa: wielkopolskie, kujawsko-pomorskie i pomorskie.

Region ten przez większość swojej historii stanowił pogranicze między różnymi bytami państwowymi. Stąd nazwa oznaczająca „kraj na rubieży” czy „na skraju”. Już w średniowieczu oddzielał Królestwo Polskie od księstw pomorskich. Także w dwudziestoleciu międzywojennym przez ten obszar przebiegała granica między II Rzeczpospolitą a Niemcami (Jakubowski 2018: 12). Ze względu na swoje położenie Krajna i jej mieszkańcy ulegali wpływom różnych kręgów kulturowych, zarówno narodowych, jak i regionalnych. Region ukształtowały kultura polska i niemiecka, a jego wewnętrzne zróżnicowanie wynika dodatkowo ze znaczących wpływów wielkopolskich, zwłaszcza w południowej części Krajny, oraz kaszubskich, w części północnej (Angutek 2013: 45-47).

Charakterystyka dwóch krajeńskich wsi, Iłowa i Lutowa, będących obszarem naszych badań, bardzo dobrze obrazuje wspomnianą różnorodność. Obie wsie położone są w województwie kujawsko-pomorskim, powiecie sępoleńskim, w zachodniej części gminy Sępólno Krajeńskie. Mimo że dzieli je zaledwie nieco ponad 5 kilometrów, ich dzieje były zdecydowanie odmienne.

Po odzyskaniu niepodległości część obszaru Krajny znalazła się w granicach II Rzeczypospolitej. W całości na ziemiach polskich znalazł się powiat sępoleński, który charakteryzował się jednym z najwyższych odsetków ludności niemieckiej w ówczesnej Polsce5 (Biegański 2010: 255-259). II wojna światowa i jej skutki doprowadziły w znacznym stopniu do wymiany ludności na tych terenach. Na miejsce uciekających, a później wysiedlanych Niemców, napłynęli repatrianci z Kresów Wschodnich oraz ludność z wyniszczonej działaniami wojennymi Polski centralnej. Stopień wymiany mieszkańców poszczególnych miejscowości wpłynął w dużym stopniu na ich późniejsze losy.

Hłowo to niewielka, licząca zaledwie 300 mieszkańców wieś (Narodowy Spis Powszechny... 2015). Do połowy XIX wieku była częścią dóbr sypniewskich, a następnie stała się samodzielnym majątkiem znajdującym się do II wojny światowej w rękach rodów niemieckich. Do 1945 roku lłowo w większości było zamieszkiwane przez ewangelików, deklarujących niemiecką tożsamość narodową. Nieliczni Polacy - katolicy posiadali małe i średnie gospodarstwa oraz pracowali w majątku6. Po zakończeniu wojny większość mieszkańców Iłowa wyjechała, a na ich miejsce

5 Zgodnie ze spisem powszechnym z 1921 r. Niemcy stanowili 48\% mieszkańców powiatu, a według spisu powszechnego z 1931r. 40,4\% (Biegański 2010: 255).

6 Na tych ziemiach w okresie dwudziestolecia międzywojennego przynależność wyznaniowa pokrywała się u większości mieszkańców z przynależnością narodowo-etniczną. 
przybyli polscy przesiedleńcy. Iłowski folwark został znacjonalizowany, w jego miejscu utworzono działające do 1993 roku Państwowe Gospodarstwo Rolne, w którym większość mieszkańców wsi znalazła zatrudnienie.

We wsi do dziś znajduje się wiele dowodów na dawną obecność niemieckich - ewangelickich mieszkańców. Są to przede wszystkim neogotycki, poewangelicki kościół, obecnie pw. św. Andrzeja Boboli, zespół dworsko-folwarczny oraz dwa cmentarze ewangelickie (Biegański 2010: 514-517). Większość zabudowy wsi, w tym domy, budynki gospodarcze i szkoła, również pochodzi sprzed II wojny światowej. Wyjątek stanowią niskie bloki mieszkalne wybudowane w czasie funkcjonowania PGR-u.

Lutowo z kolei w 2011 roku liczyło 488 mieszkańców (Narodowy Spis Powszechny.. 2015). Pierwsze wzmianki o wsi pochodzą z 1370 roku, kiedy to dotychczasowi właściciele sprzedali wieś arcybiskupowi gnieźnieńskiemu. Przez wieki Lutowo należało do archidiakonatu i często było oddawane w dzierżawę w zamian za czynsz. W 1818 roku dawne ziemie arcybiskupie rozprzedano dotychczasowym dzierżawcom i nowym osadnikom (Biegański 2010: 520-521). W 1921 roku 89\% mieszkańców stanowili Polacy, 10,3\% Niemcy, a 0,7\% Żydzi.

Pierwszy kościół rzymskokatolicki powstał w Lutowie w 1652 roku. Dziś na jego miejscu stoi zabytkowy kościół z 1929 roku. Przed II wojną światową we wsi działała dwuklasowa szkoła oraz leśnictwo (Biegański 2010: 520-521). Po 1945 roku w czasach funkcjonowania Gromadzkiej Rady Narodowej w czynie społecznym powstało wiele budynków istniejących we wsi do dziś. Są to m.in. szkoła, dawna poczta, Wiejski Ośrodek Kultury czy siedziba Ochotniczej Straży Pożarnej.

Nasza praca nad mapą składała się z kilku etapów. Pierwszy etap polegał na spotkaniu z mieszkańcami wybranych miejscowości, zapoznaniu się z nimi i rozpoznaniu ważnych lokalnie miejsc podczas pracy warsztatowej, wspólnych spacerów etnograficznych po miejscowości i rysowania map. Naszymi przewodniczkami w terenie były animatorki lokalne, pracujące w Świetlicy Wiejskiej w Iłowie i w Wiejskim Domu Kultury w Lutowie, Irena Mierzejewska i Małgorzata Senska. To one kierowały nas do pierwszych rozmówców, zwoływały mieszkańców i mieszkanki na spotkania i wyjaśniały nam zawiłości lokalnych historii.

W celu poznania różnorodnych perspektyw na pierwsze spotkania badawcze zaprosiłyśmy wszystkich mieszkańców. Z naszego zaproszenia w lłowie skorzystały głównie mieszkanki działające w Kole Gospodyń Wiejskich oraz dzieci i młodzież, uczestniczący w zajęciach w świetlicy. Pierwszym wspólnym zadaniem było rysowanie mapy w podgrupach - prosiłyśmy o zaznaczenie na niej miejsc ważnych dla społeczności i dla osób rysujących. To zadanie zostało szczególnie entuzjastycznie przyjęte przez pracującą z nami grupę kobiet. Wśród śmiechu i gwaru powstało kilka map narysowanych przez najmłodszych i wspólna mapa członkiń Koła Gospodyń Wiejskich. Każda z grup następnie przedstawiała swoją mapę innym, tłumacząc umieszczenie 
na niej tych, a nie innych elementów. Mapy te były dla nas cennym źródłem informacji na temat tego, jak widzą siebie i swoją wieś ludzie w niej mieszkający oraz jak odczytują otaczającą ich architekturę, przyrodę, przestrzeń.

Na mapie kobiet znajdowała się m.in. świetlica i szkoła, sklep, kościół, kapliczka, ale też uzyskane dzięki staraniom mieszkańców chodnik i latarnia oraz poszczególne części wsi z ich lokalnymi nazwami (Wietnam, Matysiaki i Koszary). Na mapie była też „Droga do cywilizacji” (czyli droga do gminnego miasteczka, Sępólna Krajeńskiego) Przy omawianiu mapy uczestniczki żartowały, że w przeciwnym kierunku prowadzi "Ostatnia droga" (droga do oddalonego o 7 kilometrów Sypniewa, gdzie znajduje się parafialny cmentarz katolicki).

Na mapach narysowanych przez najmłodszych uczestników warsztatów ważne okazały się - poza najważniejszymi punktami, takimi jak kościół, sklep i dwór, miejsca spotkań (świetlica, przystanek PKS), domy, w których mieszkały rodziny dzieci, a także przyroda. Jeden z chłopców odwzorował bardzo dokładnie układ dróg i dróżek oraz elementy krajobrazu (szpalery drzew, las, pola), gdyż jako zapalony rowerzysta codziennie przemierzał tę przestrzeń.

Po stworzeniu map rozmawiałyśmy z uczestnikami spotkania o tym, czym jest dziedzictwo i jak jest ono lokalnie rozumiane. Już w czasie tej rozmowy pojawiły się ważne wątki, które towarzyszyły nam w późniejszej pracy nad mapą: powojenne osiedlanie się na tych terenach, językowe i kulturowe różnice między ludnością lokalną a napływową, wartość wspólnej pracy i zabawy. Następnie odbyłyśmy z kilkoma mieszkankami spacer po wsi, zatrzymując się przy ważnych punktach i słuchając opowieści uczestniczek, a także napotkanych po drodze osób. W spacerze uczestniczyły też dzieci, mające do wykonania różne zadania związane z konkretnymi punktami. Dzięki doświadczeniu spaceru i wysłuchaniu różnorodnych opowieści, mogłyśmy zacząć konstruować wspólną wyobrażeniową mapę ł owa.

Kolejnym etapem badań było poznawanie wsi i rozmowy z osobami mieszkającymi w różnych jej częściach, niejednokrotnie wskazanymi nam przez poprzednich rozmówców. Ze względu na krótki czas badań i sytuację pandemiczną nie udało nam się dotrzeć do wszystkich mieszkańców, były też miejsca gorzej przez nas rozpoznane. Starałyśmy się jednak zebrać w miarę pełny obraz miejscowości, posiłkując się materiałami źródłowymi oraz wiedzą lokalnych animatorek i historyków. Zdecydowałyśmy się uwzględniać wiele różnych wersji opowieści - nie po to, aby je porównać i sprawdzić ich poprawność, ale po to, aby oddać zmienne losy badanego miejsca i zachować wielość perspektyw. W czasie spotkań i rozmów osoby mieszkające obecnie lub niegdyś w Iłowie pokazywały nam często zdjęcia z życia rodzinnego i gromadzkiego. Te wizualne świadectwa przeszłości pozwoliły nam lepiej zaobserwować zmiany dokonujące się w materialnym otoczeniu ludzi, stosunkach społecznych czy krajobrazie. Nierzadko, wracając do przeszłych wydarzeń, rozmówcy wyrażali tęsknotę za czasami młodości, ale też za wspólnotowością, gwarem i ruchem, które panowały we wsi. Zeskanowane 
zdjęcia stały się też podstawą działań wspólnych - część z nich umieściłyśmy na wydrukowanej grze memory, dodatkowym elemencie projektu, który powstał ze względu na zainteresowanie dzieci i potencjałtej prostej gry w lokalnych działaniach edukacyjnych.

Mapa drukowana powstawała na podstawie zebranych przez nas rysowanych map, indywidualnych opowieści, a także doświadczeń poruszania się po badanej miejscowości. Pod koniec badań wróciłyśmy do naszych rozmówców i rozmówczyń z własnoręcznie narysowaną mapą z zaznaczonymi na niej punktami, ponieważ chciałyśmy uwzględnić wszystkie indywidualne głosy i historie, a także skonsultować mapę z osobami, które aktywnie uczestniczyły w procesie jej tworzenia. Po konsultacjach okazało się, że część punktów należy przenieść, inne z kolei miały różne nazwy, o czym dużo dyskutowałyśmy. Mieszkanki proponowały też umieszczenie niektórych osób i etnografek na mapie, co podkreślało relacje, które łączą poszczególnych ludzi ze sobą i z miejscem. Na drukowanej mapie nie znaleźli się ostatecznie ludzie, ale - mamy nadzieję - widać na niej szczególną relację mieszkańców z przestrzenią: przydomowymi ogródkami, miejscami związanymi z przetwarzaniem jedzenia, lasami i łąkami, okolicznymi jeziorami, ale też budowaną w czynie społecznym szkołą podstawową (dziś pełniącą funkcję świetlicy), likwidowanym i otwieranym na nowo sklepem, czy pałacem, gdzie pracowano i mieszkano w czasie, gdy istniał we wsi PGR.

Pod koniec badań terenowych dołączyła do nas graficzka. Zależało nam na tym, by zobaczyła przestrzeń, której mapę będzie tworzyć, by miała szansę porozmawiać z mieszkankami i mieszkańcami. Projekty mapy, stworzone później przez graficzkę, trafiły do mieszkańców miejscowości, ponieważ chciałyśmy się upewnić, że na mapie pojawią się wszystkie ważne miejsca. Informacje umieściłyśmy równolegle na internetowej wersji mapy, która miała zapewnić możliwość modyfikacji treści, dodania nowych informacji oraz zamieszczenia fotografii?

Mapy, powstałe dzięki naszym działaniom, pokazują różne sposoby, w jakie mieszkańcy miejscowości patrzą na swoje miejsce zamieszkania i jego okolice. Chciałyśmy, żeby było na nich widoczne to, co jest ważne dla naszych rozmówców: zarówno w odniesieniu do przeszłości, jak i w obecnym życiu wsi. Starałyśmy się umieścić na mapie różne warstwy czasowe zasłyszanych opowieści - czasy przedwojenne, stanowiące odległą historię dla dużej części rozmówców, trudne lata powojenne, okres rozkwitu PGR-u, niestabilne lata 90., aż po współczesne zmiany demograficzne oraz infrastrukturalne na wsi.

Interesowało nas to, w jaki sposób historie pojedynczych ludzi i grup społecznych łączą się z konkretnymi przestrzeniami. Mieszkaniec sąsiedniej wsi po zapoznaniu się z mapą napisał nam, że przejeżdżając w najbliższym czasie przez Iłowo z pewnością spojrzy na nie inaczej. Wiadomość ta pokazuje, że udało nam się osiągnąć jeden z celów projektu: wydobywanie z zebranych opowieści informacji, które pozwalają odkrywać

7 Mapę można oglądać na stronie: https://mapa.etnograficzna.pl/. 
na nowo dobrze znane miejsca. Na wyobraźnię mogą działać informacje o budynkach i przestrzeniach, które zmieniły swoją funkcję, jak łąka, obecnie stanowiąca wyłącznie pastwisko, a niegdyś wykorzystywana również jako przestrzeń spotkań i zabaw: „W niedziele tutaj były tylko same koce, dzieci, piłki różne, zabawki... Jako małe dzieci to daleko nigdzie się nie chodziło, ale było zawsze wesoło".

Miejsca z pozoru tak banalne, jak droga czy las, mogą wiązać się nie tylko ze wspomnieniami niosącymi emocje, ale także ze śladami działań poszczególnych osób. Jedna z rozmówczyń tak opowiadała o budowie drogi w ramach szarwarku. „I tam na tej drodze, jak byśmy jechali, to odcinek mogę pokazać, na którym ja pracowałam Te kamienie na wóz wrzucałam, później z woza na drogę. Czternaście lat miałam”. Historie wkładu pojedynczych ludzi w zmienianie się przestrzeni miejscowości to nie tylko domena przeszłości: jeden z punktów na mapie łłowa dotyczy latarni, o której postawienie przez lata walczyła jedna z mieszkanek. Latarnia ostatecznie stanęła, niestety pomysłodawczyni nie doczekała tego momentu.

Relacje zbierane w terenie nierzadko nie są spójne - różne osoby potrafią przekazywać znacznie różniące się od siebie informacje dotyczące tych samych miejsc. Czasem możliwe jest uwzględnienie różnych wersji historii - takie rozwiązanie przyjęłyśmy w przypadku wyjaśniania na mapie etymologii nazwy „Diabli Kąt”:

Nazwa „Diabli Kąt” na pewno jest stara, ponieważ widnieje na mapach z końca XIX wieku, zapisana po niemiecku jako „Teufelswinkel”. Skąd się wzięła? Niektórzy twierdzą, że to miejsce, gdzie Diabeł mówi dobranoc, daleko od głównych zabudowań wsi. Inni wspominają historię wypadku, do którego mogło dojść w tamtej okolicy. Ostatnie z wyjaśnień to legenda, w której „tu Diabeł szedł i tak ogonem machał, jak machnął to są te doliny, a ta ziemia, co wyleciała, to te górki”. Alternatywną nazwę „Anielskie Góry” zaproponował po wojnie jeden z księży. Dlaczego? Tu znów opinie się różnią, jedni uważają, że księdzu nie wypadało używać diabelskiej nazwy, drudzy podkreślają przymioty mieszkańców tych okolic, do których znacznie bardziej pasują anielskie określenia (Bińka, Orlikowska, Patzer, Płuciennik, Wojtaszczyk 2020a).

Choć sięgnięcie do dodatkowych źródeł, np. do dokumentów historycznych, czasem uzupełniało wiedzę zdobytą w terenie o wartościowe informacje, naszym celem nie było jednak rozwikłanie zagadek historycznych, a raczej zebranie obrazów przeszłości funkcjonujących w pamięci mieszkańców. W takie podejście nieuchronnie wpisane są pewien subiektywizm i fragmentaryczność.

Opowieści umieszczone na naszej mapie są niekiedy zaskakująco lokalne. Choć łłowo nie jest dużą miejscowością, mieszkańcom głównej części wsi historie

8 Szarwark - obowiązek dostarczania ludzi i wozów do robót publicznych, nakładany przez państwo na ludność wiejską do 1958 r.; też: praca w ramach tego obowiązku; za: Słownik Języka Polskiego (https://s.jp.pwn.pl/). 


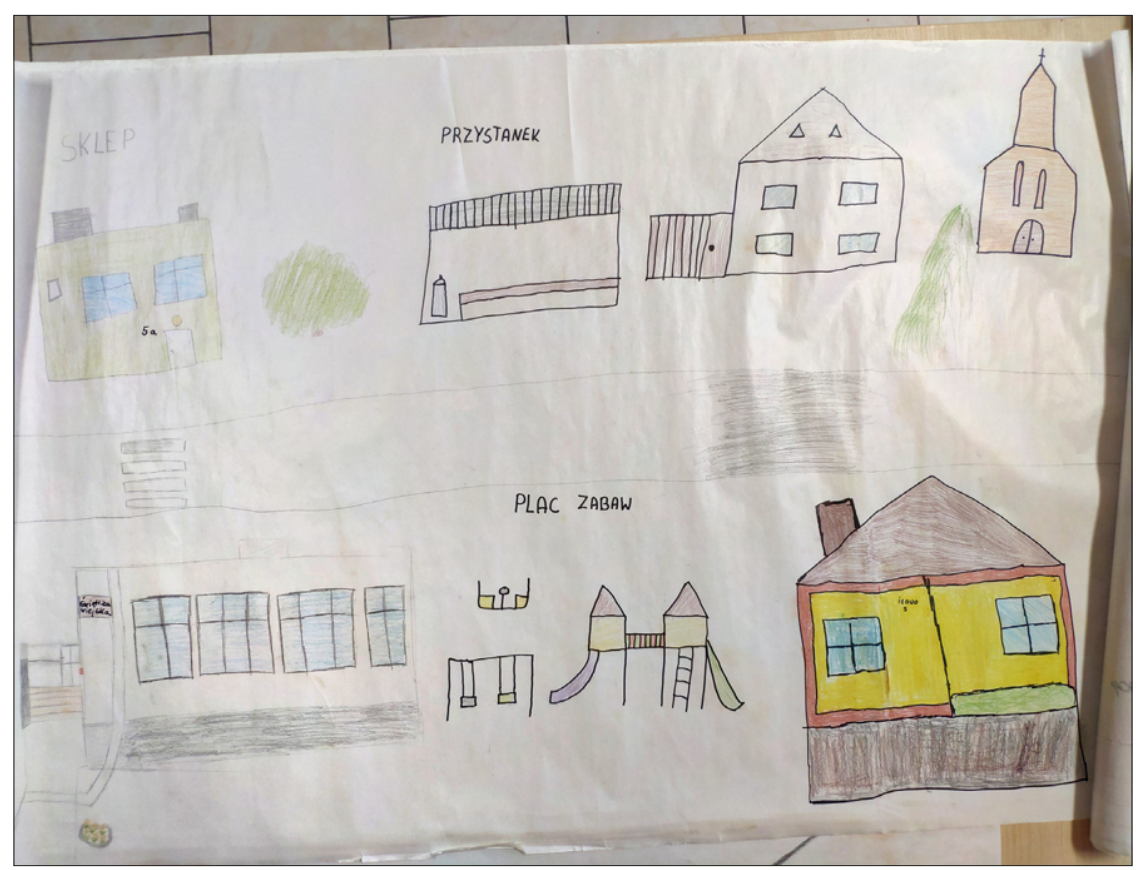

II. 3.

Mapa ważnych miejsc w lłowie narysowana przez grupę dzieci podczas pierwszego spotkania

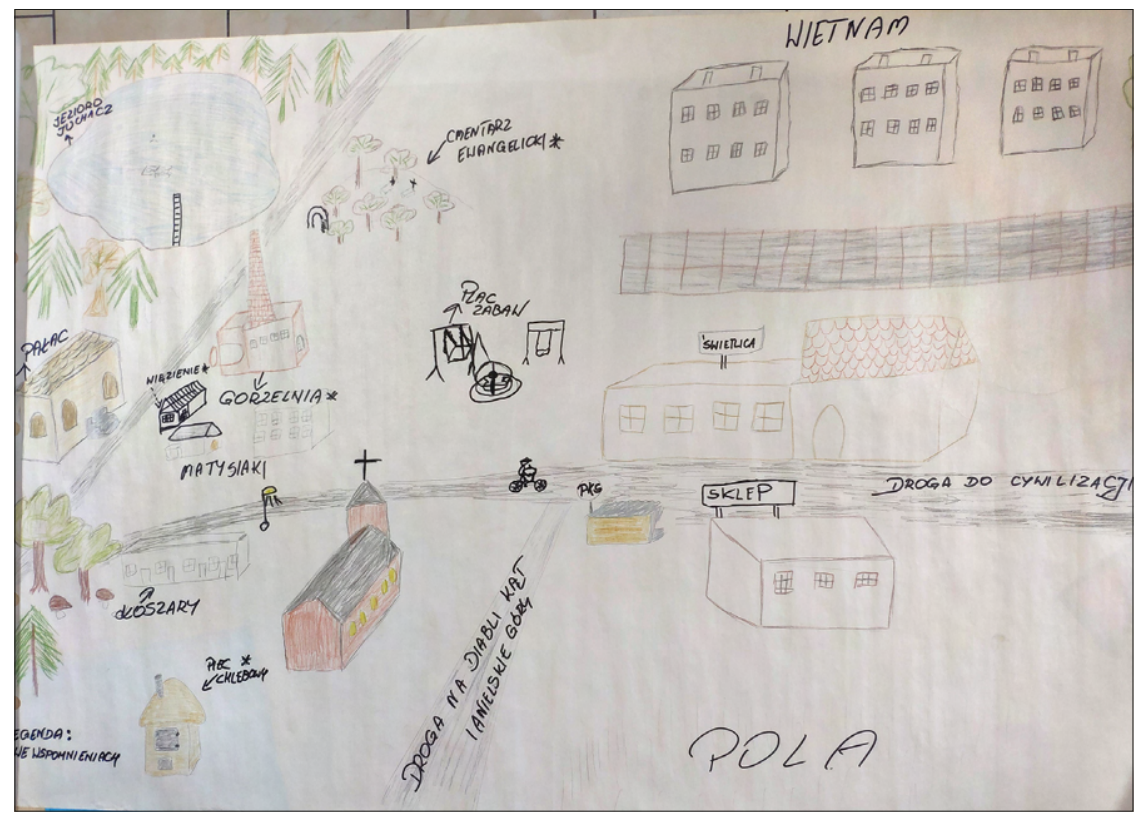

II. 4.

Mapa ważnych miejsc w Iłowie autorstwa członkiń Koła Gospodyń Wiejskich 


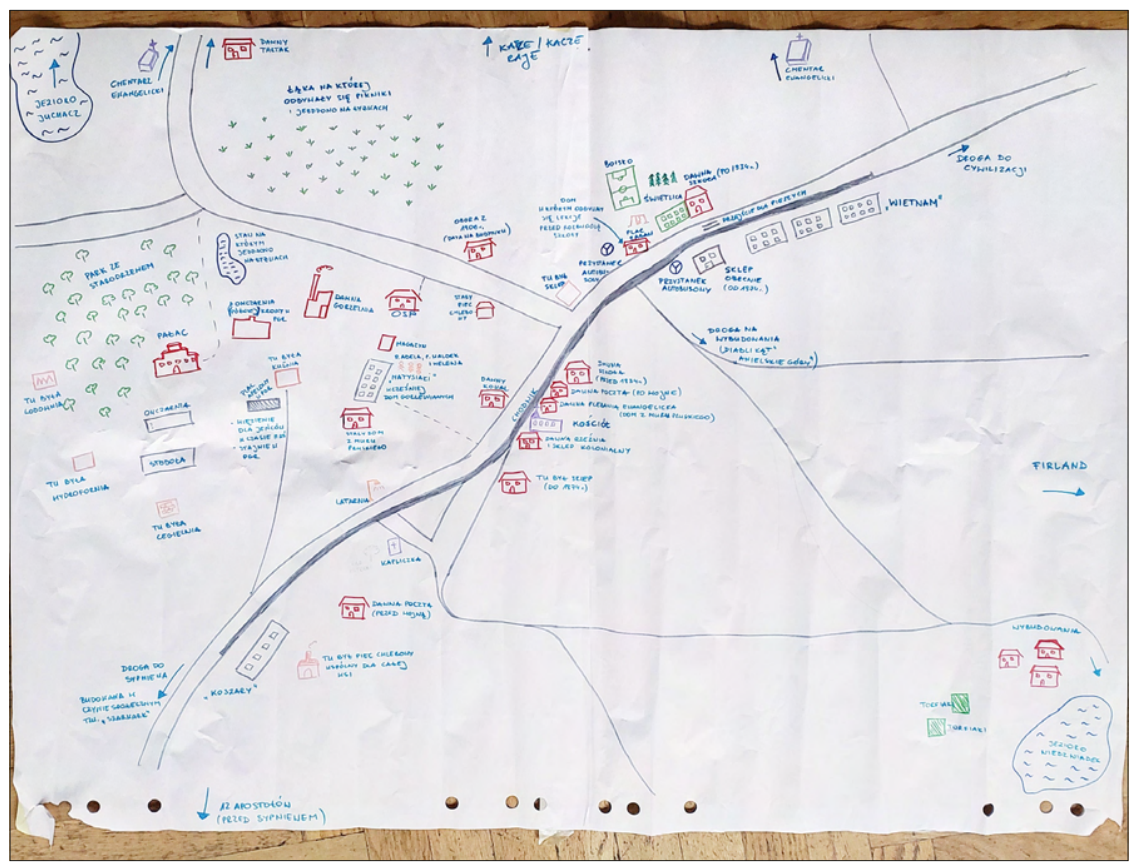

II. 5.

Mapa Iłowa zaprezentowana społeczności pod koniec pobytu etnografek, zbierająca informacje z różnych źródeł

z wybudowań9 są w dużej mierze obce. Mapa staje się okazją, aby zebrać w jednym miejscu wiele informacji nieznanych ogółowi mieszkańców, a funkcjonujących w ramach mniejszych sieci relacji. Niewielkie jezioro Niedźwiadek pojawiło się na naszej mapie dopiero po wizycie w gospodarstwach położonych na „Diablim Kącie". Choć jest ono bardzo ważnym miejscem dla mieszkańców tej części Iłowa, to nie stanowi istotnego punktu odniesienia dla osób z innych części wsi. Podobnym przykładem jest opowieść o leśnym grobie sąsiada, niemieckiego gospodarza, zabitego przez Armię Czerwoną w 1945 roku. Jest ona znana przede wszystkim mieszkańcom najbliższej okolicy, którzy jeszcze wiele lat po wojnie nazywali pobliski zagajnik „kajzowymi brzózkami” - od nazwiska zabitego gospodarza, Kajze. Frapująca była dla nas także historia jednego z dwóch ewangelickich cmentarzy w Iłowie, o którym trudno było zdobyć jakiekolwiek informacje. Większość mieszkańców, mimo że była świadoma jego obecności, niewiele na ten temat wiedziała. Dopiero rozmowa z mieszkającym poza Iłowem potomkiem pochowanych tam osób pozwoliła nam poznać opowieść o tym miejscu.

Tereny naszych działań mają złożoną historię, która odbija się w życiorysach ich obecnych i dawnych mieszkańców - Polaków, Niemców, katolików i ewangelików, 


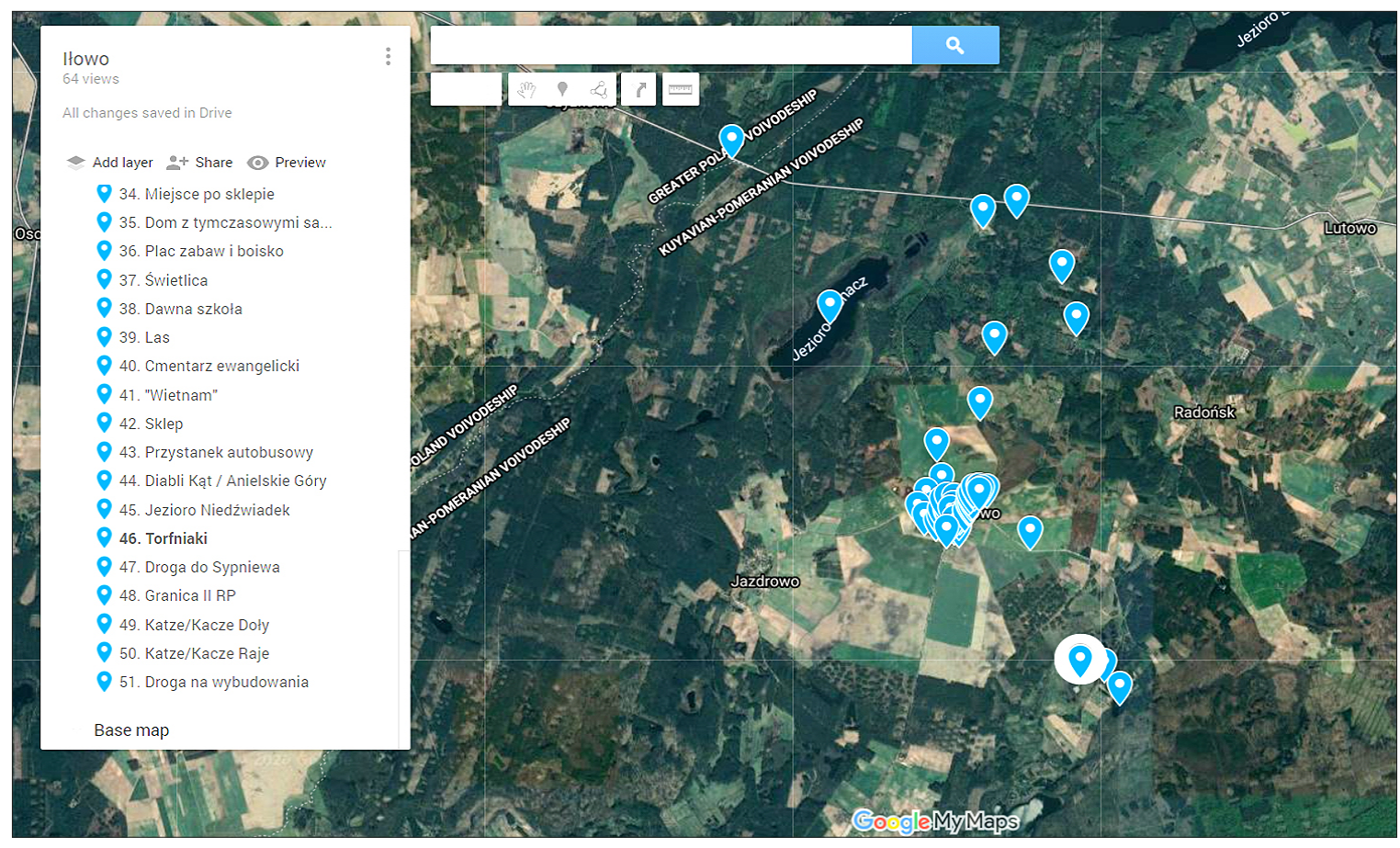

II. 6.

Praca nad ustaleniem szczegółowej lokalizacji i ostatecznym wyborem miejsc do naniesienia na docelowej mapie

osób z rodzin mieszanych, mieszkających tu od pokoleń i przyjezdnych. Było dla nas istotne, by spróbować chociaż trochę zrozumieć tę różnorodność historycznych doświadczeń i opowiedzieć o niej. W rozmowach z mieszkańcami zdarzało nam się dotykać tematów bardzo trudnych, takich jak powojenna przemoc wobec osób pochodzenia niemieckiego oraz ewangelików, którzy zdecydowali się zostać w Polsce. Te indywidualne historie często nie są znane całej społeczności. Jeden z rozmówców, pochodzący z mieszanej, polsko-niemieckiej rodziny, opowiadał wręcz o wymazywaniu śladów po dawnych mieszkańcach łłowa: „To wszystko zostało rozebrane po wojnie, zniknęło z mapy i pamięci". Wciąż mierzymy się z pytaniem, jak przekazywać dalej te relacje. W tym przypadku mapa okazuje się zbyt mało pojemnym narzędziem, pozwalającym jedynie zasygnalizować trudne kwestie.

Mapy Iłowa i Lutowa powstały przede wszystkim dla mieszkańców miejscowości - jako sposób zilustrowania bogactwa dziedzictwa ich społeczności, zaprezentowania wyników badań, w których uczestniczyli, zachęty do dalszego zgłębiania lokalnych historii. Z ich reakcji wynika, że przynajmniej częściowo spełniły swoją rolę: przede wszystkim pokazały wartości, które mają jako wspólnota. 


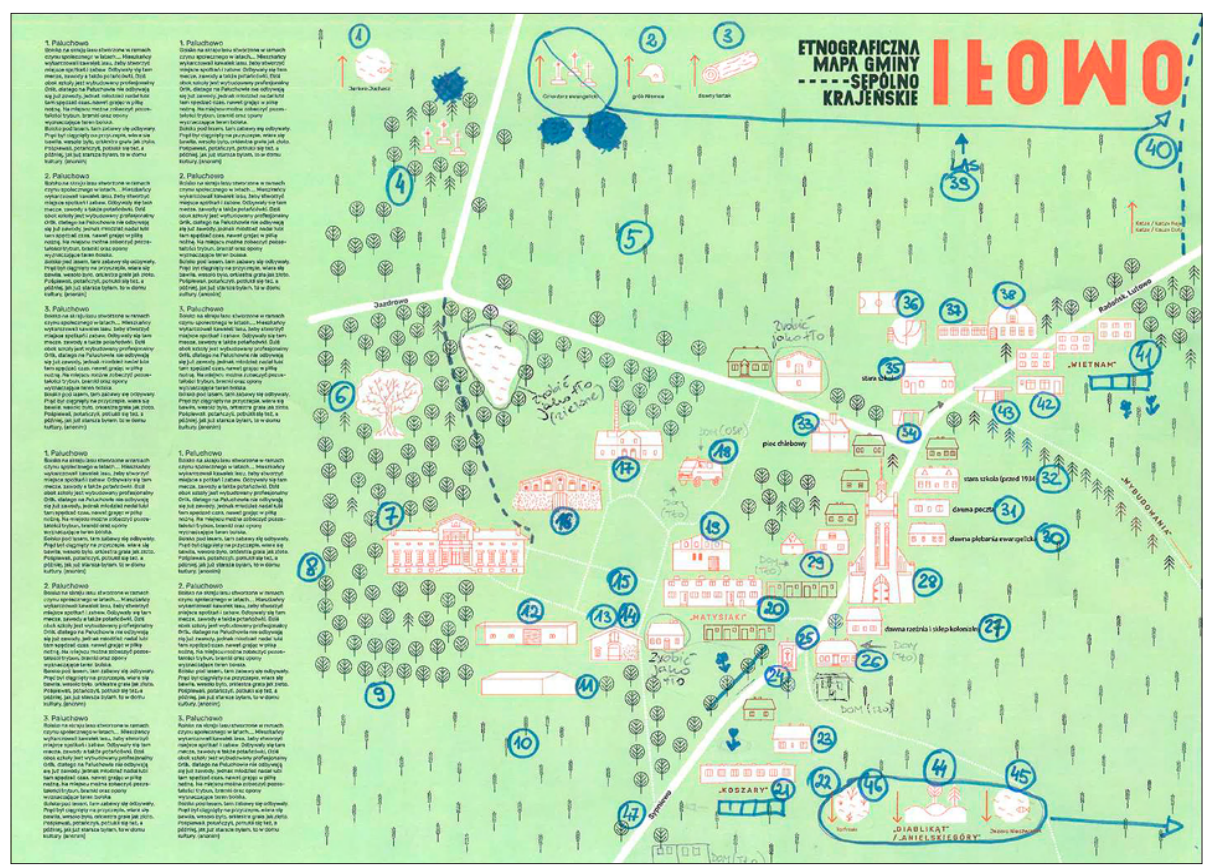

II. 7.

Współpraca z graficzką: doprecyzowanie lokalizacji i kształtu piktogramów

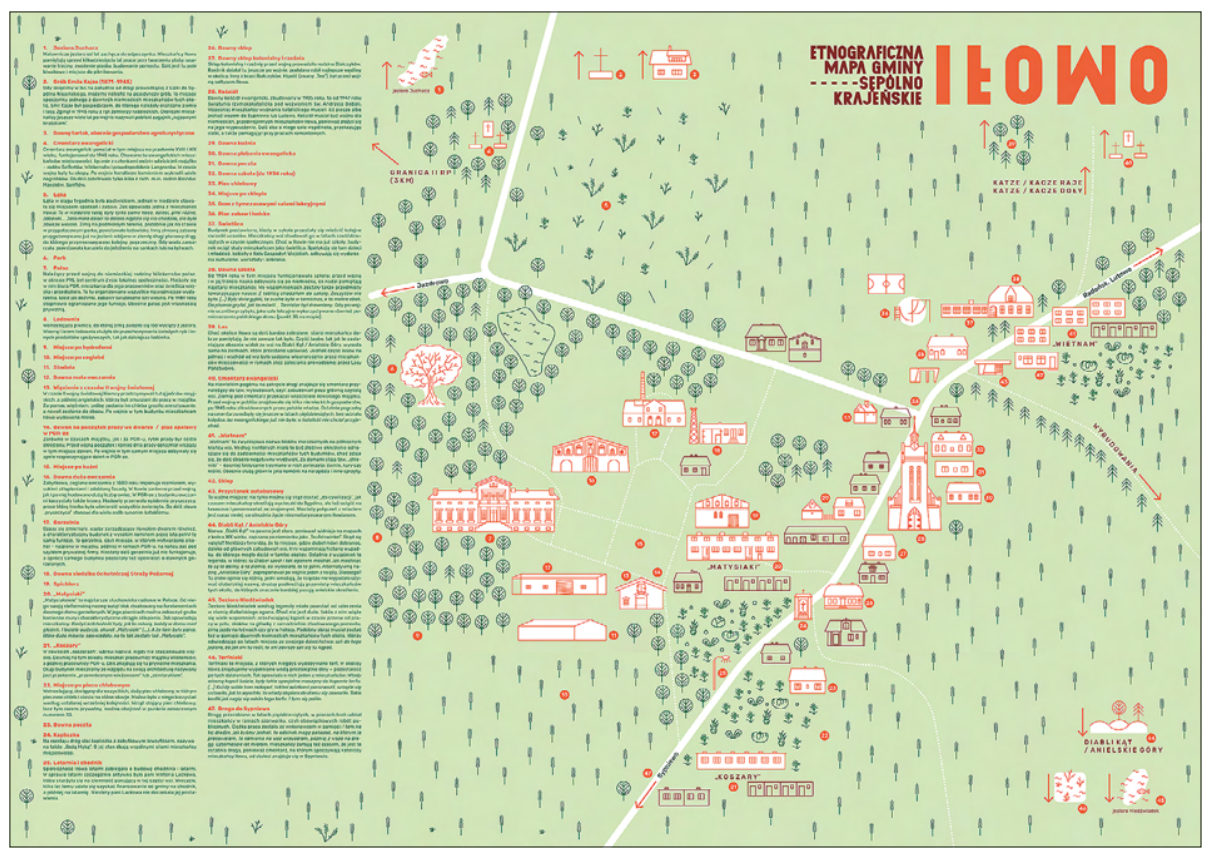

II. 8.

Ostateczny wygląd mapy Iłowa 


\section{Podsumowanie}

Mapy Kruszynian, Iłowa i Lutowa zostały opracowane na podstawie materiału etnograficznego i podobnie, jak w wielu innych naszych projektach, skierowane były do lokalnych społeczności, o których opowiadają, oraz do osób zainteresowanych ich dziedzictwem. Wiąże się to z innego typu odpowiedzialnością autorów za dobór treści przeznaczonych na mapę. Jak w każdych badaniach terenowych, potrzebne nam było zrozumienie lokalnych konfliktów i napięć. Naszym celem nie było jednak ich opisanie, a raczej pokazanie tego, co łączy mieszkańców poszczególnych wsi. Mapa etnograficzna, w zaproponowanym przez nas rozumieniu, jest do tego bardzo dobrym narzędziem, ponieważ pozwala na uwzględnienie różnych głosów i perspektyw w syntetycznej, wizualno-tekstowej formie. Taki sposób prezentowania informacji wiąże się jednak z pewnym ryzykiem. Antropolog Markus Idvall pisze: „Tworzenie reprezentacji kartograficznych jest podyktowane dążeniem do ukazania przestrzeni całościowo" (Idvall 2000: 255). My jednak, tworząc mapę etnograficzną, mamy świadomość jej niekompletności i fragmentaryczności, jak również subiektywnego charakteru przekazywanych treści. Zazwyczaj mapa ma formę zamkniętą, a odbiorcy traktują ją jako źródło obiektywnych danych. W przypadku mapy etnograficznej mogą z tego wynikać nieporozumienia, spowodowane traktowaniem opowieści na niej zawartych jako źródła informacji historycznych.

Na wszystkich etapach realizacji projektów korzystamy z doświadczeń zdobytych podczas wcześniejszej pracy ze społecznościami lokalnymi. Staramy się docierać do różnych grup mieszkańców, nie zatrzymując się na sugestiach osób wskazanych przez lokalne autorytety i instytucje. Podczas dokonywania wyboru ostatecznej listy punktów na mapę, dążymy do zachowania wrażliwości na różnorodność perspektyw i doświadczeń. Pisząc teksty pozwalamy wybrzmieć głosom mieszkańców. Opracowując formę graficzną natomiast, dbamy o to, by na mapie znalazły się wszystkie ważne dla członków wspólnoty miejsca, nawet jeśli tylko symbolicznie zaznaczone: przy dużej skali może to być wręcz każdy budynek, gdyż dla rozmówców odnalezienie swojego domu na mapie okazywało się ważne.

Nasze mapy, ze względu zarówno na treść, jak i na formę, wpisują się w nurt dążący do zmiany narracji o polskiej wsi. Tomasz Rakowski, pisząc o poznawaniu na nowo historii społeczności wiejskich w czasach PRL-u, zachęca także do działań będących próbą „rozmontowania jednostronnego, stereotypowego wizerunku wsi, obrazu niepełności, braku kompetencji obywatelskich, nieprzygotowania społecznego" (2016: 105). 0 tym, że takie działania są potrzebne ze względu na rozpowszechnione autostereotypy mieszkańców wsi, a jednocześnie mogą faktycznie wpływać na zmianę postrzegania dziedzictwa własnej miejscowości, świadczy zdanie jednej z naszych rozmówczyń z Iłowa, skierowane do nas po zapoznaniu się z mapą: „Nie myślałam, że w tak szarej popegeerowskiej wsi coś tam jednak tkwi". 
Stereotypowy obraz wsi wiąże się też z jej folkloryzacją (por. Klekot 2016), w wyniku której tam, gdzie mieszkańcy nie dostrzegają efektownych elementów dziedzictwa kulturowego, pojawia się deprecjonowanie własnych tradycji czy wręcz przeświadczenie o ich braku. Mamy wrażenie, że bywa to jedną z przyczyn formułowania tak często słyszanych przez nas uwag „u nas nie ma nic ciekawego”, „nie mamy żadnych specjalnych tradycji". Naszą metodą jest uważne wsłuchiwanie się w opowieści mieszkańców wsi o ich doświadczaniu codzienności i przeszłości. Takie podejście pozwala odnaleźć nieoczywiste warte opowiadania historie, zarówno w miejscowościach rozpoznawalnych, mających pewną charakterystyczną dominującą opowieść, jak i w takich, które są znane głównie swoim mieszkańcom i które dopiero mogą zostać odkryte przez innych.

\section{Bibliografia}

Angutek, D. (2013). Kulturowe wymiary krajobrazu. Antropologiczne studium recepcji przyrody na prowincji: od teorii do empirii. Poznań: Bogucki Wydawnictwo Naukowe.

Biegański, Z. (red.) (2010). Dzieje Sępólna Krajeńskiego. Sępólno Krajeńskie: Biblioteka Publiczna im. Jarosława Iwaszkiewicza w Sępólnie Krajeńskim.

Bińka, A., Kotowska, K., Orlikowska, J., Patzer, H., Płuciennik, O., Wojtaszczyk, M. (2020a). Etnograficzna mapa gminy Sępólno Krajeńskie. Iłowo. Warszawa: Stowarzyszenie „Pracownia Etnograficzna" im. Witolda Dynowskiego.

Bińka, A., Kotowska, K., Orlikowska, J., Patzer, H., Płuciennik, O., Wojtaszczyk, M. (2020b). Etnograficzna mapa gminy Sępólno Krajeńskie. Lutowo. Warszawa: Stowarzyszenie „Pracownia Etnograficzna" im. Witolda Dynowskiego.

Bloch, N. (2016). Wszyscy jesteśmy migrantami. (Od)zyskiwanie migracyjnej pamięci. Poznań: Centrum Kultury ZAMEK

Ciuńczyk, A. (2013). Znachor Gródecki. Gródek: Towarzystwo Przyjaciół Ziemi Gródeckiej.

Czyżewska, A. (2019). Animacja po sępoleńsku. Diagnoza potrzeb kulturalnych i potencjału kulturotwórczego gminy Sępólno Krajeńskie. Warszawa: Stowarzyszenie „Pracownia Etnograficzna” im. Witolda Dynowskiego.

Demski, M., Kojder, K., Kościańska, J., Płuciennik, O. (2019). Jest w tej wsi coś niezwykłego. Opowieści o Kruszynianach. Warszawa: Stowarzyszenie „Pracownia Etnograficzna”.

Epsztein, M., Górna, A., Górny K. (2016). Percepcja przestrzeni geograficznej wśród uczniów szkół rejonu solecznickiego na Litwie. W: M.W. Solarz (red.), Polacy na Litwie. Cztery szkice do obrazu polskiego mikrokosmosu (s. 75-115). Warszawa: Wydział Geografii i Studiów Regionalnych Uniwersytetu Warszawskiego, Trzecia Strona.

Idvall, M. (2000). The Region as Sensuous Geography. W: P.O. Berg, A. Linde-Laursen, O. Löfgren (red.), Invoking a Transnational Metropolis. The Making of the Öresund Region (s. 255-275). Lund: Studentlitteratur $\mathrm{AB}$.

Ingold, T., Kurttila, T, (2000). Perceiving the Environment in Finnish Lapland. Bodyand Society, 6(34), 183-196

Jakubowski, Ł. (2018). Krajeński las rzeczy. Szkice z dziejów Sępólna Krajeńskiego i okolic. Sępólno Krajeńskie: Biblioteka Publiczna im. Jarosława Iwaszkiewicza w Sępólnie Krajeńskim. 
Kirshenblatt-Gimblett, B. (2011). Od etnologii do dziedzictwa. Rola muzeum. etnografia nowa, 3, 125-136.

Klekot, E.(2016). Lud na wsi: dlaczego poza twórcami ludowymi nikt na wsi nie lubi sztuki ludowej? W: A. Bińka, J. Kościańska, J. Orlikowska, J. Szymańska (oprac.), Nasze miejsce. Inspirator do pracy z lokalnością (s. 97-107). Warszawa: Stowarzyszenie „Pracownia Etnograficzna” im. Witolda Dynowskiego.

Kłodnicki, J., Pieńkos, A., Koźmińska, J. (2017). Polski atlas etnograficzny. Historia, osiągnięcia, perspektywy badawcze. Katowice: Wydawnictwo Uniwersytetu Śląskiego.

Kondracki, J. (2002). Geografia regionalna Polski. Warszawa: PWN.

Lynch, K. (1960). The Image of the City. Cambridge: The MIT Press.

Małanicz-Przybylska, (2016). Skąd jesteśmy - kim jesteśmy? W: A. Bińka, J. Kościańska, J. Orlikowska, J. Szymańska (oprac.), Nasze miejsce. Inspirator do pracy z lokalnością (s. 97-107). Warszawa: Stowarzyszenie „Pracownia Etnograficzna” im. Witolda Dynowskiego.

Narodowy Spis Powszechny... (2015). Narodowy Spis Powszechny Ludności i Mieszkań 2011. Warszawa: Główny Urząd Statystyczny. Pozyskane z: https://stat.gov.pl/spisy-powszechne/nsp-2011/.

Nasze miejsce... (2016). Nasze miejsce. Inspirator do pracy z lokalnością, oprac. A. Bińka, J. Kościańska, J. Orlikowska, J.Szymańska. Warszawa: Stowarzyszenie „Pracownia Etnograficzna” im. Witolda Dynowskiego.

Nasze miejsce... (2020). Nasze miejsce. Projekt edukacji etnograficznej dla dzieci i młodzieży, oprac. M. Demski, K. Kamler, K. Kojder, J. Kościańska, J. Orlikowska, O. Płuciennik. Warszawa: Stowarzyszenie „Pracownia Etnograficzna” im. Witolda Dynowskiego.

Pawluczuk, W. (1974). Wierszalin. Reportaż o końcu świata. Warszawa: Wydawnictwo Literackie.

Prymaka-Oniszk, A. (2017). Bieżeństwo 1915. Zapomniani uchodźcy. Wołowiec: Wydawnictwo Czarne.

Rakowski, T. (2016). Działania edukacyjne w przestrzeniach wsi. Odkrywanie podmiotowości środowisk wiejskich. W: A. Bińka, J. Kościańska, J. Orlikowska, J. Szymańska (oprac.), Inspirator do pracy z lokalnością (s. 97-107), Warszawa: Stowarzyszenie „Pracownia Etnograficzna” im. Witolda Dynowskiego.

Skorowidz miejscowości Rzeczypospolitej... (1924). Skorowidz miejscowości Rzeczypospolitej Polskiej, opracowany na podstawie wyników pierwszego powszechnego spisu ludności z dn. 30 września 1921r. i innych źródeł urzędowych. T.5, Województwo białostockie. Warszawa: Główny Urząd Statystyczny

Słownik Języka Polskiego. Pozyskano z: https://sjp.pwn.pl/.

Shils, E. (1984). Tradycja (przeł. J. Szacki). W: J. Kurczewska, J.Szacki (red.), Tradycja i nowoczesność (s. 30-89). Warszawa: Wydawnictwo Czytelnik.

Wojtaszczyk, M., Solarz M.W. (2016). Świat w oczach mieszkańców oaz Liwa. Próba diagnozy w oparciu o mapy pamięciowe. W: I. Łęcka (red.), Rozwój w warunkach pustynnych: oazy Liwa w Zjednoczonych Emiratach Arabskich (s. 154-180). Warszawa: Wydawnictwa Uniwersytetu Warszawskiego.

\section{Spis fotografii}

Fot.1. Meczet współcześnie. Kruszyniany, 2019 r. Fot. K. Kojder.

Fot.2. Dawna cerkiew. Kruszyniany. Fot. W. Hulanicki, ze zbiorów Wojewódzkiego Urzędu Ochrony Zabytków.

Fot.3. Młodzi ludzie przed barem Złota Orda. Kruszyniany. Ze zbiorów Bronisława Talkowskiego.

Fot.4. Kiosk Ruchu. Kruszyniany, 1979 r. Fot. I. Kabat, ze zbiorów Cyfrowego Archiwum im. Józefa Burszty. 


\section{Spis ilustracji}

II.1. Materialne rezultaty projektu. Oprac. K. Kojder.

II.2. Mapa Kruszynian z opisami poszczególnych miejsc. Oprac. M. Demski, K. Kojder, K. Kotowska, J. Kościańska, O. Płuciennik.

II.3. Mapa ważnych miejsc w Iłowie narysowana przez grupę dzieci podczas pierwszego spotkania. Źródło: Archiwum Stowarzyszenia „Pracownia Etnograficzna”.

II.4. Mapa ważnych miejsc w Iłowie autorstwa członkiń Koła Gospodyń Wiejskich. Źródło: Archiwum Stowarzyszenia „Pracownia Etnograficzna”.

II.5. Mapa Iłowa zaprezentowana społeczności pod koniec pobytu etnografek, zbierająca informacje z różnych źródeł. Źródło: Archiwum Stowarzyszenia „Pracownia Etnograficzna”.

II.6. Praca nad ustaleniem szczegółowej lokalizacji i ostatecznym wyborem miejsc do naniesienia na docelowej mapie. Zrzut ekranu z aplikacji Google Maps.

I1.7. Współpraca z graficzką: doprecyzowanie lokalizacji i kształtu piktogramów. Źródło: Archiwum Stowarzyszenia „Pracownia Etnograficzna”.

I.8. Ostateczny wygląd mapy Iłowa. Oprac. A. Bińka, K. Kotowska, H. Patzer, J. Orlikowska, O. Płuciennik, M. Wojtaszczyk.

\section{Streszczenie}

Artykuł prezentuje mapy etnograficzne, które zostały stworzone w ramach dwóch projektów Stowarzyszenia „Pracownia Etnograficzna”, realizowanych w społecznościach lokalnych na Podlasiu i na Krajnie. W artykule pokazujemy, jak przebiegał proces powstawania map w badanych miejscowościach. Pomimo różnic łączy je fakt, że powstały dzięki współpracy etnografek z mieszkańcami miejscowości, a przedstawione na nich treści wyłoniły się dzięki wspólnemu przyglądaniu się lokalnemu dziedzictwu. Celem artykułu jest refleksja nad mapami etnograficznymi jako narzędziem pracy ze społecznościami lokalnymi i jako sposobem na oddanie głosu mieszkankom i mieszkańcom. Zastanawiamy się, jakie zalety ma wykorzystanie tego narzędzia oraz z jakimi wiąże się wyzwaniami. Skłania nas to też do refleksji nad charakterem wiedzy zdobytej i przedstawionej w ten sposób, a także nad wpływem naszych działań na badane społeczności.

Słowa klucze: mapy, etnografia, dziedzictwo, społeczności lokalne

\section{Summary}

The article presents ethnographic maps created in the framework of two projects of the "Ethnographic Laboratory" Association, which have been realized in the Podlasie and Krajna region. In the article we show how the process of making the maps proceeded in the researched communities. Despite the differences, all the maps are a result of the cooperation between ethnographers and the inhabitants of the villages, and the content of the map itself is a result of looking at local heritage together. The aim of the article is to reflect on ethnographic maps as a tool for working with local communities, and as a way to let their members' voices be heard. We ponder upon the advantages of using this tool, and the challenges it entails. This also makes us reflect on the nature of the knowledge acquired and presented in this way, and the impact of our activities on the studied communities.

Keywords: maps, ethnography, heritage, local communities 
